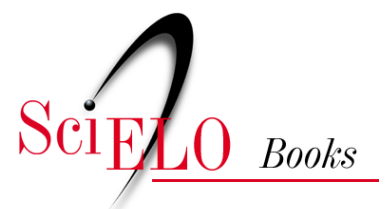

\title{
3. A primeira república e a constituição de uma rede hospitalar no Distrito Federal
}

\author{
Gisele Sanglard
}

\section{SciELO Books / SciELO Livros / SciELO Libros}

SANGLARD, G. A primeira república e a constituição de uma rede hospitalar no Distrito Federal. In: PORTO, Â., SANGLARD, G., FONSECA, M.R.F., and COSTA, R.G.R., orgs. História da saúde no Rio de Janeiro: instituições e patrimônio arquitetônico (1808-1958) [online]. Rio de Janeiro: Editora FIOCRUZ, 2008, pp. 59-87. ISBN: 978-85-7541-599-3. Available from: doi:

$10.7476 / 9788575415993.0005$. Also available in ePUB from:

http://books.scielo.org/id/7f83x/epub/porto-9788575415993.epub.

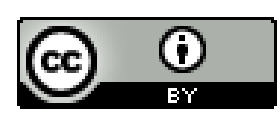

All the contents of this work, except where otherwise noted, is licensed under a Creative Commons Attribution $\underline{4.0 \text { International license. }}$

Todo o conteúdo deste trabalho, exceto quando houver ressalva, é publicado sob a licença Creative Commons Atribição 4.0. 
3

A Primeira República e a Constituição de
uma Rede Hospitalar no Distrito Federal

Gisele Sanglard 


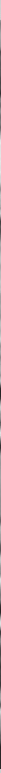


O estudo aqui apresentado remonta ao início da República, mais especificamente entre os anos 1906 e 1929, quando se percebe um evidente contraste no que concerne às atuais concepções sobre saúde, bem como à própria esfera de ação do Estado. A análise se concentrará nas idéias e propostas a respeito da constituição da rede hospitalar na cidade do Rio de Janeiro, então Distrito Federal, presentes no debate que perdurou ao longo daquele período, envolvendo médicos, higienistas e filantropos. Chama a atenção nesse debate a definição de assistência pública, a qual não possui nenhuma similaridade com o atual significado de assistência médica, embora se tratasse da prestação de certos serviços médicos à população. Entendia-se como assistência pública um vasto e abrangente leque de ações às quais se atribuía caráter público - desde os cuidados com a infância e a maternidade até aqueles com a velhice e a loucura - e que envolvia um conjunto de instituições públicas e privadas, laicas e religiosas - hospitais, asilos, orfanatos, colônias, creches, ligas, postos médicos, maternidades, hospícios, dispensários, policlínicas-, cujos limites de atuação eram tênues e permeáveis.

Quando se analisam as transformações pelas quais passou a assistência pública, com base nas discussões e nas propostas apresentadas por médicos e por representantes da elite da época, torna-se possível definir esse período como uma transição entre o Estado liberal, tal como estruturado pela Constituição de 1889, e um Estado de bem-estar social, que caracterizou a chamada Era Vargas (1930-1945), que será tratada no capítulo seguinte. Percebe-se que, naquele momento, questionamentos e incertezas cercavam o liberalismo da nascente República, e identifica-se ali o surgimento de propostas e ações que seriam implementadas durante a década de 1930 .

Este capítulo está dividido em quatro partes. Na primeira, "O hospital e seu público", discuto as transformações no hospital - de lugar da caridade a espaço da terapêutica. Esse tema está relacionado com a percepção da sociedade sobre o pobre, a quem esse espaço foi destinado ao longo dos séculos, e o surgimento do operariado, que requer uma outra estrutura de assistência. Na segunda parte, "A assistência no Brasil: primeiras organizações", procuro explicitar a característica da assistência no país, centrada nas ações pias da Irmandade da Misericórdia, e as mudanças advindas com a Proclamação da República. Na terceira parte, "Repensando a assistência pública (1900-1918)", deixo a palavra aos médicos e filantropos que apresentam seus projetos para a Assistência Pública no Distrito Federal - ainda baseada na nãointervenção do Estado. Esses homens defendiam a participação da filantropia na organização da assistência. Por fim, na última parte, "A crise de leitos e as mudanças na assistência (1918-1919)", evidencio 
a passagem do Estado liberal para o de bem-estar-social. O ano de 1922 marca o último sopro de uma assistência em moldes liberais, enquanto médicos e políticos defendem seus projetos, agora clamando pela participação na criação e gestão da rede de hospitais públicos na cidade. Período de transição, no qual a fala dos médicos deixa transparecer toda a incerteza que marca a década.

\section{O Hospital e seu Público}

O hospital é um lugar para onde se acorre em momentos de doença, para tratamento clínico e cirúrgico. Contudo, a relação dos homens com essa instituição nem sempre foi assim, tendo sofrido grandes transformações ao longo dos séculos. Os hospitais eram o lugar do pobre, aonde se ia buscar alimento para o corpo e para a alma.

Na Idade Média, os hospitais - palavra cuja etimologia está ligada ao ato de hospedar - eram abertos aos acometidos por todas as mazelas humanas: os loucos, as parturientes, os enjeitados, os velhos e os doentes. Essas instituições eram o lugar, por excelência, da caridade, mesmo que em alguns momentos de sua história tenham sido usadas para fins de manutenção da ordem pública.

Desde suas origens, pode-se caracterizar o hospital por seu aspecto notadamente religioso e de centro social para atendimento à população carente — e será difícil extrair-lhe essa marca, até porque a pobreza e o cuidado dos pobres são questões centrais do cristianismo. No início, as inquietações com a salvação e a compaixão com o enfermo motivaram grande parte das doações às instituições hospitalares. Os períodos de epidemias marcavam um aumento das contribuições, que podiam ser feitas sob a forma de legados e doações ou pelo recolhimento de esmolas. Deve-se atentar para o fato de que, naquela época, o pobre era revestido de um manto santificado, era o pobre de Deus, e ao ato de abrigá-lo era atribuído igualmente um caráter sagrado. Com o tempo, as questões ligadas ao mundo terreno passaram a predominar nas relações entre a sociedade e esses estabelecimentos, transformando-os aos poucos. A partir do século XVI, foi sobretudo um novo olhar sobre o pobre e a pobreza que alterou a feição dos hospitais. O manto santificado foi posto de lado, dando lugar à idéia de que uma aglomeração de pobres representava um perigo social em potencial.

No início do século XVIII o lixo, a sujeira, as águas paradas, a exalação de odores putrefatos passaram a ser considerados como ambientes propícios para a disseminação de doenças. Por isso, as ruas das cidades, os cemitérios e as moradias insalubres foram alvo da atenção e da ação higienista. Em diversos países constituíram-se organizações sanitárias públicas visando ao controle de epidemias e pestes, cuja atuação mais visível foi aquela voltada para tais ambientes (Bourdelais, 2001; Corbain, 1986). A essa nova situação outras seriam acrescentadas, como a preocupação com a circulação, com as cidades e com as condições de vida (alimentação, moradia etc.) e trabalho. O hospital não se manteve alheio a esse clima e tornou-se um dos focos principais do problema, tendo sido aberta uma cruzada contra a aglomeração que os caracterizava (ocupação dos leitos e enfermarias, localização das salas etc.) em prol da aeração e da insolação - dois conceitos caros aos higienistas. ${ }^{1}$ No entanto, a partir do processo de reforma, ele se converteu em uma peça essencial na política sanitária e demográfica posta em prática na Europa ao longo do século XIX, não só devido aos melhores equipamentos disponíveis, mas sobretudo em virtude da formação de seu corpo médico. Era somente no hospital e na prática cotidiana que o conhecimento médico poderia ser adquirido, o que reafirmava o seu papel de equipamento médico. 
Desde o início do século XIX, já se percebia o uso da linguagem da higiene pública entre os médicos e a elite, sobretudo ao se referirem a situações definidas como sociais e nelas intervirem; os pobres eram, para eles, o foco dos principais problemas da cidade. Contudo, nesse período, paralelamente ao processo de industrialização, um novo personagem entrou em cena: o operário. Não era mais o pobre o objeto da atenção de higienistas e filantropos, mas sim o operário e suas condições de vida e habitação. Era para ele que a Lei dos Pobres inglesa, de 1834, estava voltada; ${ }^{2}$ e diversas ações filantrópicas e legislativas foram postas em prática na França, a reboque dos movimentos sociais que singularizaram o século XIX e a gênese do pensamento socialista.

É nesse quadro que surgem os "reformadores sociais", como eles se autodenominaram - intelectuais, médicos, industriais e políticos que se propuseram a pensar um novo pacto social para a França. Contrapunham-se aos "filantropos", aos quais atribuíam uma resposta ineficaz às necessidades sociais, em um momento em que eram redefinidas as fronteiras entre as esferas pública e privada, por terem tomado como objeto de atuação o 'operário' e não mais o 'pobre', anunciando um longo debate sobre a legitimidade do papel do Estado na sociedade industrial. Esses 'reformadores' tinham por objetivo alcançar a paz social, em um momento marcado pelas agitações sociais. As ações propostas por eles estavam direcionadas para a criação de habitações salubres voltadas para o operariado, o que demonstrava uma forte influência do credo higienista, mediante a criação de uma legislação protetora e de incentivos aos círculos operários, organizados nas fábricas, objetivando também a educação cívica e o lazer (Duprat, 1993). Foram defensores das sociedades de auxílio mútuo, que visavam ao socorro em caso de doença, acidente, velhice, maternidade ou morte e eram consideradas como uma necessidade do mundo do trabalho. A mutualidade era percebida como estrutura complementar para a organização dos operários e proposta em consonância com a prática liberal então vigente (Horne, 2004).

As necessidades do 'mundo do trabalho' acabaram por trazer alterações na dinâmica da assistência, obrigando-a a se adequar à matriz da vida e da cultura modernas - a indústria e suas conseqüências: acidentes de trabalho, desemprego, más condições de habitação etc. Foi nessas circunstâncias que surgiu, no século XIX, uma outra forma de assistência: as caixas de socorro mútuo ligadas às categorias profissionais. Ao lado dos serviços hospitalares, a educação sanitária passou a fazer parte das ações das caixas de socorro, tornando-se essas instituições, nas palavras de Olivier Faure (1993: 120), "instrumentos de higienização" da saúde tanto física quanto moral do trabalhador pobre. Espaço de socialização de classes, socorros médicos, previdência e poupança, as caixas de socorros mútuos se tornaram, aos olhos da elite, o lugar por excelência para o crescimento moral das classes trabalhadoras.

Foi nesse contexto de transformações que médicos e filantropos brasileiros -mesmo que restritos ao Rio de Janeiro - conceberam a assistência no Brasil e sobre ela refletiram.

\section{A Assistência no Brasil: primeiras organizações}

A assistência no Brasil se caracterizou, desde o início da colonização, por uma dependência das ações da Irmandade da Misericórdia. A Irmandade de Nossa Senhora, Madre de Deus, Virgem Maria da Misericórdia, ou simplesmente Misericórdia, foi criada em Portugal no final do século XV sob os auspícios da rainha d. Leonor, o que lhe garantiu prestígio e proteção régia, diferenciando-a das outras confrarias 
criadas na mesma época. Suas obras (hospital, Casa da Roda, recolhimento das órfãs) eram sustentadas por esmolas, doações pias dos fiéis, legados testamentais e dotações dos governos, fosse, cada um a seu tempo, a Coroa portuguesa, o governo imperial, ou o republicano (cf. verbete do Hospital da Santa Casa da Misericórdia do Rio de Janeiro, no CD-ROM).

A concentração da assistência na Misericórdia, desde o início do século XVI, fez parte de um conjunto de ações postas em prática pela Coroa portuguesa, que "lançaram os alicerces de um sistema de apoio social, relativamente uniformizado, assente numa explícita lógica de divisão de funções, que ambicionava abranger os presos, as crianças desprotegidas, os pobres e os doentes" (Abreu, 2004: 13) Foi essa mesma 'uniformização' do sistema que se expandiu por todo império ultramarino português, onde muitas vezes as Misericórdias representavam o poder colonial, misturando-se, nas suas ações, constantemente, o público e o privado.

A Irmandade da Misericórdia assumiu, na colônia, o papel de instituição pública, não só por receber o padroado régio, mas também por duas outras razões. A primeira vincula-se diretamente à organização do Estado imperial: em 1828 este delegou às províncias e aos municípios a responsabilidade pelas ações de saúde - retomando o controle das ações após a eclosão da primeira epidemia de febre amarela na Corte, no verão de 1849-1850 -, enquanto que ao governo imperial caberia agir apenas nos tempos de epidemias, na manutenção dos hospitais de isolamento (Marítimo de Santa Isabel ${ }^{3}$ e, a partir de 1886, o Hospital São Sebastião), na saúde dos portos e na fiscalização do exercício da medicina e da farmácia.

A segunda razão está ligada, justamente, à percepção da fronteira entre o público e privado tanto no período imperial quanto na Primeira República. Apesar de estarem aparentemente atuando em campos opostos, as ações dos diferentes agentes envolvidos com a assistência eram, muitas vezes, complementares. A instituição podia ser de caráter privado, mas sua 'ação' era pública. Ou, dito de outra forma:

Distintas foram, sim, as formas de gestão das variadíssimas instituições assistenciais; as tutelas que sobre elas se exerceram; as denominações - ou os significados de denominações semelhantes -; os tempos de intervenção dos poderes institucionais. Comum foi também, muitas vezes, a interatividade, quando não a complementaridade, entre os diferentes organismos envolvidos na assistência, mesmo quando posicionados em campos opostos. (Abreu, 2004: 11)

Pública ou privada, laica ou confessional, a assistência no Rio de Janeiro, e no Brasil, era realizada por diversas instituições e denominações assistenciais, que em épocas de necessidade se voltavam para socorrer os pobres.

No que tange à assistência hospitalar propriamente dita, a cidade do Rio de Janeiro contava com um grande número de hospitais, policlínicas e casas de saúde, que por mais que reservassem leitos à filantropia, pouco alteravam no cômputo geral a disponibilidade de leitos para os desvalidos. A ausência de um hospital gerido pela municipalidade causava estranhamento aos estrangeiros que por aqui aportavam, como o caso do francês Émille Allain (1886), que visitou a cidade no final do Império, apesar de considerar que o serviço de assistência pública estava muito bem organizado, graças à ação da Santa Casa da Misericórdia.

Em 1889, o advento da República alterou sobremaneira a organização das competências municipal e federal. O que até então cabia ao poder central passou a ser exercido pela municipalidade, como explicitado anteriormente. Assim, coube ao município do Distrito Federal gerir todas as ações de higiene urbana. 
Entre as diversas medidas tomadas pela prefeitura, pode-se citar a derrubada do cortiço Cabeça-de-Porco, no Centro do Rio de Janeiro, em fevereiro de 1893 - exatamente um ano após a promulgação da lei que deu poderes à prefeitura para atuar na higiene da cidade. ${ }^{4}$ Assim, a destruição do Cabeça-de-Porco na gestão do médico e prefeito Barata Ribeiro (1892-1893) reforçou a vitória da política higienista e abriu o período de forte intervenção pela qual cidade que passaria ainda na gestão do prefeito Pereira Passos (1902-1906) - o Rio do bota-abaixo. A ação demolidora culminou com a derrubada do morro do Castelo, na gestão do prefeito Carlos Sampaio (1920-1922), visando a todas as referidas medidas de melhorias das condições higiênicas e sanitárias da cidade.

Se por um lado as medidas da prefeitura se concentraram na questão urbana, com as melhorias das condições sanitárias e seu embelezamento, por outro os primeiros anos da República pouco alteraram a estrutura da assistência hospitalar na capital. A Santa Casa da Misericórdia continuava como o único hospital destinado ao atendimento dos desvalidos, mas contava com a ajuda da Policlínica Geral do Rio de Janeiro (1881) e da Policlínica de Botafogo (1899), instituições filantrópicas que prestavam atendimento ambulatorial, clínico e cirúrgico aos indigentes.

No entanto, no início do século essa estrutura ainda não era um problema para os médicos, como expressou Luiz Barbosa (1869-1949). Para ele, a capital não carecia, em 1908, de instituições de assistência, mas sim de uma forma coerente de organização e administração. O médico explicitava, em sua obra sobre os Serviços de Assistência no Rio de Janeiro, de 1908, que a classificação das instituições entre oficiais - federais e municipais - e particulares - religiosas e civis - podia ser considerada artificial, mas era plenamente aceitável para o desenvolvimento de seu livro e, em todo o caso, todos os estabelecimentos, institutos, associações e serviços de assistência trabalhavam em prol da assistência pública na cidade (Barbosa, 1908).

Vale ressaltar que uma das principais características da $1^{a}$ República foi o federalismo, que transferia aos estados a responsabilidade pelas ações de manutenção da ordem e de proteção das populações, em contraposição à centralização do poder durante o Império. Esse federalismo era legitimado pela prática liberal que propugnava a não-intervenção do Estado, o que sustentava o mandonismo local. E no que tange à assistência, a prática liberal acabava por manter a estrutura herdada dos tempos coloniais, a cargo da Misericórdia. Assim, ao Estado caberia agir apenas em tempos de grande calamidade pública, quando a ordem estivesse em perigo, ou seja, durante as epidemias; e na fiscalização dos portos e do exercício profissional.

\section{Repensando a Assistência Pública (1900-1918)}

Os primeiros anos do século XX foram marcados pela intervenção da Prefeitura do Distrito Federal nas condições higiênicas da cidade, tendo permanecido as ações de assistência tais quais as do Império. Durante a presidência de Rodrigues Alves (1902-1906), empreenderam-se reformas modernizadoras na capital federal, em três frentes de ação que se sobrepunham: o porto, a cidade e seus problemas sanitários.

Essas três frentes voltavam-se para uma questão de ordem pública: os antigos casarões do Centro que haviam se transformado em habitações coletivas dos trabalhadores portuários. Esses prédios eram majoritariamente ocupados por negros egressos das fazendas, que afluíram à cidade após a abolição da 
escravatura em busca de trabalho e o encontraram no porto, onde a mão-de-obra era absorvida na carga e descarga de navios que aportavam em número cada vez maior. Vinham, portanto, aos olhos das autoridades, aumentar o já numeroso contingente de ex-escravos e libertos que circulavam pela cidade. Assim, os inúmeros cortiços que existiam eram considerados ameaças públicas à ordem, segurança, moralidade, salubridade, e como tais deviam ser controlados e combatidos. Parece que, aos olhos dos republicanos, o pobre se tornara perigoso, pois colocava em risco seus planos de construção de uma nação civilizada e industrial nos trópicos (Benchimol, 1992; Chalhoub, 2004).

A Reforma Sanitária configurou-se, ao mesmo tempo, como objeto de ação e justificativa para o projeto modernizador (Benchimol, 2001). Coube ao médico Oswaldo Cruz chefiar a Diretoria-Geral da Saúde Pública (DGSP), órgão que centralizou as ações de saúde pública na capital. Oswaldo Cruz foi investido de poderes de polícia que lhe permitiram invadir residências, estabelecimentos comerciais e industriais, a fim de identificar focos de epidemias, bem como de adotar as necessárias medidas profiláticas.

Uma das conseqüências dessa reforma foi a perda, por parte da Prefeitura do Distrito Federal, ${ }^{5}$ da maior parte de suas atribuições, que passaram a ser centralizadas na esfera federal, à exceção dos socorros médicos de urgência. Embora lamentando essa medida, o médico Luiz Barbosa reconhecia que, apesar da obrigação da prefeitura de 'fundar, dirigir e organizar' os postos de assistência e do seu 'dever' de prestar socorro de urgência em casos de acidentes nas ruas e nos balneários, pouca coisa havia sido realizada. Foi iniciativa da municipalidade criar, em 1903, o Ofício Geral de Assistência, que teria como objetivo organizar as diversas iniciativas filantrópicas de assistência espalhadas pela cidade, e no ano seguinte, a primeira tentativa de organização dos serviços de urgência. A primeira medida não chegou a ser implementada e a segunda, na opinião do médico, trouxe vícios antigos, notadamente porque os referidos serviços de urgência foram instalados em prédios impróprios e não contavam com material suficiente para as funções clínicas e administrativas. Contudo, a assistência de urgência tomou outros rumos com inauguração, no dia $1^{\circ}$ de novembro de 1907, do Posto Municipal de Assistência, na rua Camerino, o atual Hospital Municipal Souza Aguiar.

Paralelamente ao rearranjo das atuações e competências dos poderes municipal e federal na cidade do Rio de Janeiro, os primeiros anos do século XX viram surgir diversos congressos dedicados ao tema da assistência pública e privada, onde médicos e filantropos encontraram o palco ideal para defender suas idéias sobre o assunto. Essa discussão estava em consonância direta com as idéias debatidas em todo o mundo ocidental, quando, como já dito aqui, o papel do Estado na sociedade estava sendo discutido e questionado (Polanyi, 2000). Foi nesse contexto de rearticulação e de redefinição dos papéis sociais que se conceberam propostas para a assistência pública e privada, tema extremamente caro aos liberais. Essa discussão não ocorreu, contudo, ao mesmo tempo em todos os países, elas perpassaram todo o século XIX e início do século XX e estavam diretamente relacionadas aos momentos históricos vividos pelos Estados nacionais. ${ }^{6}$

Entre as personagens que apresentaram propostas para a organização da assistência na capital brasileira, destacaram-se os médicos Luiz Barbosa, Carlos Arthur Moncorvo de Figueiredo Filho (Moncorvo Filho), Antônio Fernandes Figueira, Garfield de Almeida e o filantropo Ataulfo Nápoles de Paiva.

Luiz Barbosa apresentou, em sua obra já citada de 1908, como deveria ser organizada a assistência pública pela prefeitura. Defendia a aplicação, na capital, de um sistema de socorro similar ao de Buenos 
Aires, em que a cidade foi dividida por distritos de atuação dos socorros e as ambulâncias seriam dirigidas por acadêmicos de medicina. A comparação entre as duas capitais sul-americanas era bem desfavorável ao Rio de Janeiro, onde o transporte de doentes e feridos se fazia em padiolas emprestadas ou em veículos da Assistência Policial e, na maior parte das vezes, sem exame médico. Barbosa sugeria um acordo com o governo federal para instalar seus postos nas delegacias de saúde e o aproveitamento das policlínicas como recurso complementar aos socorros de urgência. Vale ressaltar que Luiz Barbosa foi o criador da Policlínica de Botafogo, além de ter dirigido a Assistência Pública Municipal, no período.

Em 1907, Moncorvo Filho (1871-1944) publicou o folheto “Assistência pública no Rio de Janeiro e particularmente da Assistência à Infância", fruto de sua comunicação no IV Congresso Internacional de Assistência Pública e Privada realizado em Milão, no ano anterior, onde fez um balanço da situação da assistência no Rio de Janeiro e propôs medidas para melhor organizá-la. Afirmava que, segundo as "modernas doutrinas", cabia às municipalidades a organização dos serviços de assistência, e à União o estabelecimento de leis gerais de assistência e a organização do órgão central, que deveria presidir todo o movimento, orientando os diversos serviços, de caráter privado ou nacional.

Moncorvo descrevia brevemente a situação das instituições privadas, ${ }^{7}$ com mais ênfase na Santa Casa da Misericórdia. A esta atribuía sérios problemas, alguns considerados como "de origem" - o fato de ser uma instituição de caridade -; outros devidos aos inúmeros doentes que era obrigada a aceitar, "debaixo de seu caridoso teto", bem como aos atendimentos de emergência (acidentes de rua e outros), para os quais não estava preparada e que deveriam ser feitos pela municipalidade; ou mesmo devido à planta do prédio, considerada como obsoleta e que, por exemplo, deixava as enfermarias muito próximas umas das outras. Todos esses fatores contribuíram para que o atendimento na Santa Casa fosse deficitário. Concluiu afirmando que as lacunas deixadas no atendimento na Santa Casa eram plenamente aceitáveis em face dos inúmeros serviços e encargos que ela suportava (Moncorvo Filho, 1907).

Opinião semelhante foi expressa pelo médico Antônio Fernandes Figueira, em 1902, nas páginas do periódico Brazil-Médico. Para ele, era urgente a melhoria do serviço hospitalar na cidade no que tangia ao atendimento às crianças, à questão do isolamento e às instalações hospitalares, sobretudo ao se anexar as enfermarias aos serviços clínicos. Mesmo que houvesse movimentação de criação de hospitais pela municipalidade, ele acreditava que o mais importante era introduzir reformas "nas casas santas, a que vão ter os doentes sem recursos" (Figueira, 1902: 311-312), além de separar crianças de adultos e contar com isolamentos mais definidos a fim de não misturar variolosos com tuberculosos e pestilentos. Para Fernandes Figueira, essa era a maior obra que o provedor da Santa Casa poderia realizar.

Como se verá mais adiante, o discurso sobre a superlotação da Santa Casa da Misericórdia era uma constante na fala dos médicos, mesmo que a irmandade mantivesse diversos outros hospitais ou buscasse abrir novas instituições - como a Policlínica das Crianças e o Hospital São Zaccharias, abertos respectivamente em 1909 e 1916, ambos destinados ao atendimento da puericultura intra e extra-uterina -, para atender a uma demanda deles mesmos.

Voltando às idéias defendidas por Moncorvo Filho no congresso de 1906, ele propunha, em uma perspectiva bem próxima daquela da prática francesa - centrada na ação dos bureaux de higiene municipais (Bourdelais, 2005) -, a criação de um Conselho Superior de Assistência Pública e de um Serviço de Assistência Pública que deveria constituir um ramo autônomo da administração pública, com receita 
própria. Suas ações estariam voltadas para os socorros em domicílio e para aqueles proporcionados nos hospitais, hospícios, dispensários, policlínicas etc., sob jurisdição do Ministério da Justiça e Negócios Interiores.

No caso específico da capital federal, Moncorvo Filho defendia a criação de um Escritório Central, onde funcionaria a sede da Assistência Pública. Em cada bairro, seriam instalados escritórios de beneficência, que contariam com postos médico-cirúrgicos, aparelhados para atendimento de emergência, diurna e noturna, e dos acidentes da via pública. Os escritórios também teriam como funções organizar as listas de indigentes e necessitados da circunscrição e dar assistência em domicílio.

Como medida prática e visando ao bom funcionamento da estrutura, Moncorvo Filho previu a utilização de instituições de assistência amplamente reconhecidas como postos de assistência - as policlínicas gerais do Rio de Janeiro e de Botafogo e o Hospital da Santa Casa da Misericórdia. O Instituto de Proteção e Assistência à Infância (Ipai) ficaria reservado à assistência à infância, incluindo exame e atestação de amas-de-leite mercenárias, fornecimento de leite aos recém-nascidos pobres e a assistência em domicílio às mulheres grávidas pobres. As mulheres que não pudessem ser atendidas no Ipai seriam encaminhadas à Maternidade de Laranjeiras ou à Santa Casa. Já os tuberculosos seriam encaminhados à Liga Brasileira contra a Tuberculose.

Novamente, as policlínicas apareceram como recursos a serem somados à Assistência Pública. Vale ressaltar que, tal qual Luiz Barbosa, Moncorvo Filho era intimamente ligado ao projeto filantrópico das policlínicas, pois seu pai fora um dos fundadores da Policlínica Geral do Rio de Janeiro, e ele mesmo o criador do Ipai. Ambos os médicos apostavam fortemente na aliança entre a filantropia e a Assistência Pública, bem como na proposta de assistência defendida por essas instituições.

Em 1908, a Prefeitura do Distrito Federal, na gestão de Francisco Marcelino de Souza Aguiar (19061909), promoveu um Congresso Nacional de Assistência Pública e Privada, realizado durante a exposição comemorativa do centenário da abertura dos portos. A comissão organizadora indicada era formada pelos médicos Benjamin da Rocha Faria e Antônio Fernandes Figueira, pelo jurista e filantropo Ataulfo Nápoles de Paiva, pelo poeta Olavo Bilac, além de João Carneiro de Souza Bandeira, Alfredo da Graça Couto e José de Medeiros e Albuquerque. Foram enviados convites às sociedades científicas, às faculdades de medicina, aos hospitais públicos e privados, às sociedades de beneficência e a todas as pessoas que se preocupavam com o problema da assistência.

O congresso foi divido em quatro sessões: Assistência médica; Assistência pública em geral; Assistência à infância; Assistência externa. Entre as diversas teses defendidas no congresso e publicadas na BrazilMédico de 1908, destacam-se as de Antônio Fernandes Figueira e de Garfield de Almeida.

O relatório apresentado por Fernandes Figueira para a sessão "Assistência pública: assistência à infância e particularmente o que se refere às medidas a adotar contra a mortalidade infantil. Educação das crianças deficientes" previa as seguintes medidas: organização, por parte do poder público, de um corpo de inspetores-médicos para a fiscalização das lactantes; obrigação das instituições de assistência aceitarem como fundamento a amamentação de crianças até os seis meses de vida; extinção das 'rodas', ${ }^{8}$ substituídas pelos 'registros livres'; urgência de fundação de sociedades de assistência em domicílio às puérperas e de proteção à amamentação materna; a criação do maior número possível de 'consultórios de lactantes' nas cidades e aldeias; a fiscalização, por parte do poder público, do leite destinado ao consumo das crianças (Figueira, 1908). 
Garfield de Almeida (1908), por sua vez, criticava os serviços hospitalares oferecidos na capital, além de reforçar o discurso que reafirmava o atraso do Rio de Janeiro no concernente à assistência pública. Suas conclusões indicavam o caminho para solucionar os problemas: a construção, com urgência, de um hospital público, que deveria ser instalado em terreno devoluto, em especial aproveitando um dos pavilhões da própria exposição de 1908. O sistema adotado seria o pavilhonar, com quarenta leitos em cada pavilhão, totalizando 14 pavilhões e 540 leitos, separando os doentes pelos 'três' (sic) sexos (homens, mulheres e crianças). O hospital contaria com um pavilhão menor, de observação; um pavilhão de enfermaria dupla, com quarenta leitos, para tuberculosos; um pavilhão de convalescentes, além de ambulatório com dez serviços. Outro ponto capital para ele era a ampliação do Asilo São Francisco de Assis, que seria melhor aproveitado se transformado em hospital-asilo.

O jurista Ataulfo de Paiva defendeu, por sua vez, a proposta de criação de um Ofício Central de Assistência, privado, constituído pela representação das instituições privadas. Seu projeto tinha por objetivo organizar a ação direta do poder público na execução e fornecimento de proteção à indigência em geral. Propunha a criação de uma Diretoria-Geral de Assistência Pública, sob cuja responsabilidade ficariam os serviços de socorros do governo (Paiva, 1916).

O Ofício Central de Assistência, organizado pelo poder central, teria como objetivo congregar e harmonizar os interesses da assistência pública e privada quando exercendo suas atividades gratuitamente. Esse órgão deveria preservar a autonomia e a administração das associações, casas pias, asilos, sociedades e outras instituições que exerciam a assistência privada. Somente dessa forma estaria o poder público habilitado para encaminhar e resolver "as grandes e capitais questões que afeta[va]m o exercício da assistência em geral" (Paiva, 1916: 321).

As conclusões gerais do congresso, no que tangia à assistência de urgência e à hospitalar, nos ajudam a entender as discussões que ganharam a agenda de médicos e filantropos. Quanto à primeira, os congressistas decidiram que era de competência do poder municipal, que todas as cidades com população numerosa ou industrializada deveriam ter um serviço de urgência e que o Posto Central de Assistência do Rio de Janeiro seria considerado como modelo a ser aplicado em outras cidades. Contudo, os serviços de emergência no Rio de Janeiro ainda estavam restritos aos locais onde poderiam atender com presteza, e era necessária a criação de outros postos de emergência nos distritos sanitários municipais urbanos. O congresso reafirmou a centralização das ações proposta pela Reforma da Saúde Pública de 1904, ao mesmo tempo que elogiou os trabalhos realizados pela Prefeitura do Distrito Federal em prol da assistência de urgência, mesmo que esta ainda tivesse que melhorar um pouco.

Já no que diz respeito à assistência hospitalar, o congresso concluiu que era urgente a construção de um hospital pela municipalidade do Rio de Janeiro; que eram imprescindíveis a ampliação do Asilo São Francisco de Assis e a criação de um hospital-asilo para incuráveis com capacidade de duzentos leitos, cem para cada sexo. Com isso, entrou em cena um pleito que dominou boa parte das discussões sobre a assistência nas décadas seguintes: a construção de hospitais públicos na capital federal. Esse tema tornouse ainda mais palpitante a partir de 1918, com a chegada da epidemia de gripe espanhola, que demonstrou a ineficiência dos serviços de assistência na capital.

Oito anos depois desse congresso, Ataulfo de Paiva publicou o livro Justiça e Assistência, no qual reuniu diversos artigos de sua autoria sobre temas ligados à justiça e à assistência, dissertando também 
sobre o tema do mutualismo e da assistência social, além de apresentar o prefácio por ele escrito para sua obra Assistência Pública e Privada no Rio de Janeiro, que só foi publicada em 1922, no âmbito das comemorações do centenário da Independência. Seu trabalho à frente da Liga Brasileira contra a Tuberculose o credenciou a participar de todos os congressos sobre o tema da assistência, tornando-o uma referência no assunto. Nesse livro o jurista e filantropo reafirmava seu projeto defendido no Congresso Nacional de Assistência Pública e Privada, de 1908, ao retomar os alicerces de sua concepção de assistência, fortemente inspirada na experiência francesa. O modelo francês era baseado no papel das comunas, dos departamentos e da nação na organização dos serviços de assistência; na França, a filantropia exerceu papel importante na assistência, sobretudo pela presença de inúmeros filantropos que defendiam seus ideais na Assembléia Constituinte (Faure, 1993).

Nesse prefácio, Ataulfo de Paiva fazia uma radiografia da assistência pública no Brasil, ao mesmo tempo que apresentava suas bases constituintes. ${ }^{9}$ Entre esses itens vale ressaltar que, no que tange à puericultura, Paiva defendeu as idéias propostas por Moncorvo Filho; para as mulheres a questão da assistência estava diretamente relacionada à força de trabalho e às condições de cuidado dos filhos, e assistência social seria traduzida na criação de maternidades, que salvariam o filho e a mãe.

No que se refere à assistência hospitalar, sua análise estava também baseada na experiência francesa, centrada nas associações de caridade e nas sociedades filantrópicas, e nas discussões que lá ocorreram desde o final do século XVIII e atravessaram o século XIX (Duprat, 1993, 1996; Faure, 1993; Sanglard, 2008). Tais associações e sociedades, além de distribuírem o pão, o vinho e o agasalho, também faziam visitas domiciliárias e atendimentos médicos. Sobre o hospital propriamente dito, além de ter discorrido sobre as mudanças na arquitetura hospitalar, desde Tenon, ${ }^{10}$ e ressaltado o modelo do hospital francês de Lariboisière, Ataulfo de Paiva falou do esgotamento do Hospital da Misericórdia do Rio de Janeiro e da necessidade de se construir um hospital público na capital; recuperou a fala de Garfield de Almeida no congresso de 1908, afirmando que, segundo os cálculos do médico, o hospital-modelo, aqui, deveria contar com oitocentos leitos. Por fim, encerrou a sessão com uma frase que resumia a expectativa da época em torno da construção de um hospital público no Rio de Janeiro: "Desta empresa, porém, e até esta data, ainda não se cogitou nas esferas governamentais. Nem tão cedo virá ela preencher mais uma das grandes e notáveis lacunas da assistência pública e privada no Rio de Janeiro" (Paiva, 1916: 219).

\section{A Crise de Leitos e as Mudanças na Assistência (1918-1929)}

O período entre 1917 e 1918 foi marcado por dois fatores que acabaram por influenciar e redirecionar os debates acerca da assistência de modo geral e, em específico, hospitalar: a eclosão das greves operárias no Rio de Janeiro e em São Paulo, que levaram à Câmara dos Deputados a discussão sobre o trabalho feminino e infantil, os acidentes de trabalho e a proteção social (Gomes, 1979), e a pandemia de gripe espanhola, no verão de 1918-1919, que chamou a atenção para um problema crônico dos grandes centros urbanos: a deficiência de centros de socorro à população carente. Como Ataulfo de Paiva vaticinara, nenhum movimento por parte da municipalidade ou do governo federal havia sido realizado com vista ao aumento de leitos hospitalares. 
A 'espanhola' transformou a questão da assistência hospitalar em uma das bandeiras da gestão de Carlos Chagas (1919-1926) à frente do recém-criado Departamento Nacional de Saúde Pública (DNSP). ${ }^{11}$ Nesse período foram criados diversos hospitais no Rio de Janeiro, como o Hospital Pedro II (1920), o Hospital São Francisco de Assis (1922), o Hospital Gaffrée \& Guinle (1924-1929) e o Abrigo-Hospital Arthur Bernardes (1924), e iniciadas as obras do Hospital do Câncer (1927-1935) e do Hospital de Clínicas Arthur Bernardes da Faculdade de Medicina (1926-1934), que mudariam a cara da assistência pública no Rio de Janeiro, sem contar a criação das colônias Juliano Moreira (1924) e Curupaity (1922-1928). Esses hospitais eram todos subvencionados pelo DNSP e vinculados à política de Carlos Chagas; dois deles foram construídos às expensas da filantropia da família Guinle ${ }^{12}$ (Sanglard, 2008).

O debate acerca da carência de leitos na cidade ocupou amplo espaço na imprensa cotidiana. Um dos médicos mais presentes foi José de Mendonça, que teve no Correio da Manhã o espaço, por excelência, de divulgação de suas idéias. Em 1918, logo após a chegada da 'espanhola', Mendonça propôs a construção de quatro hospitais de mil leitos cada um, nas regiões de Botafogo (próximo à faculdade), Andaraí, São Cristóvão (na parte litorânea do bairro, para socorrer os marítimos) e Méier ou Cascadura (próximo à linha da Estrada de Ferro Central do Brasil). Defendia a tese, que foi encampada por outros médicos, de que a assistência hospitalar não devia ser gratuita, mas proporcional ao que cada doente pudesse pagar; no caso de incapacidade total, caberia à municipalidade arcar com os custos.

Nesse mesmo ano, Carlos Chagas afirmou, durante homenagem aos médicos baianos no Derby Clube do Rio de Janeiro, que o Brasil precisava de novos e modernos hospitais, para atender às "nosologias habituais" e, eventualmente, às epidemias. Em seu discurso reiterou que o Hospital da Misericórdia não tinha mais condições de se expandir para atender às necessidades da assistência pública (Chagas, 1919).

Em 1920, uma proposta parecida seria defendida na Câmara dos Deputados, pelo médico gaúcho Domingos Mascarenhas, que conseguiu transformar em decreto seu projeto para a construção de três hospitais no Distrito Federal, um dos quais próximo à Faculdade de Medicina, todos com capacidade superior a mil leitos e administrados pelo DNSP e seguindo o modelo alemão de arquitetura hospitalar. Nesse projeto, a gratuidade estava garantida aos indigentes, os outros pagariam proporcionalmente às suas condições financeiras. Esse projeto foi fortemente inspirado nas idéias de José de Mendonça (Brasil, 1920) e amplamente discutido e debatido na Câmara dos Deputados com a presença dos médicos-deputados Palmeira Ripper, Zoroastro Alvarenga, Domingos Mascarenhas, Alexandrino Rocha, Raul Barroso, Dionysio Bentes, Rodrigues Lima e Teixeira Brandão, e contou com a participação de Carlos Chagas e Luiz Barbosa. Contudo, a proximidade das comemorações do centenário da Independência impediu que o Projeto Mascarenhas, como ficou conhecido, pudesse ser implantado, o que concorreu para o acirramento das críticas (Brasil, 1923). O projeto foi reeditado mais duas vezes, com alterações, sem que jamais tenha sido executado.

Das discussões acerca desse projeto vale a pena ressaltar algumas falas. Carlos Chagas, que argumentou que havia mais de cinqüenta anos não se fazia qualquer melhoramento na assistência hospitalar, apesar do aumento sempre crescente da população e, conseqüentemente, dos enfermos que a ela apelam, para reiterar a situação limite por que passavam a Santa Casa e o Hospital São Sebastião. Teixeira Brandão ressaltou a urgência de um hospital para o ensino das clínicas para a Faculdade de Medicina e defendeu a construção de hospitais para os funcionários municipais, o que descongestionaria a assistência hospitalar federal, e a criação de assistência domiciliária. Já Domingos Mascarenhas fez uma comparação negativa 
entre o Rio de Janeiro e Buenos Aires (Mendonça, 1920), tema recorrente entre médicos e intelectuais da época (Sanglard, 2007).

No âmbito das comemorações do centenário da Independência, dois eventos chamaram atenção para a questão da assistência pública na cidade. O primeiro foi a, já mencionada, publicação pela prefeitura da obra Assistência Pública e Privada no Rio de Janeiro (1922), que apresentava o histórico e as estatísticas de todas as instituições e associações existentes que prestavam assistência pública, assim como aquelas previstas, como o Hospital Gaffrée \& Guinle. O segundo foi a realização do Congresso Nacional dos Práticos, ocorrido na Policlínica Geral, que teve umas de suas sessões dedicada ao tema da assistência pública. Entre as diversas comunicações do congresso, vale ressaltar: "A verdadeira organização hospitalar e sua estrutura administrativa", "Autonomia dos hospitais; médicos e enfermeiros", "O hospital como meio de instrução prática", com relatoria de Irineu Malagueta; "Reflexões sobre a assistência hospitalar", por José de Mendonça; “Assistência pública e privada: relação e regulamentação”, por Moncorvo Filho; "O abuso da hospitalização gratuita, a verificação da indigência, e as tarifas hospitalares módicas", por Miguel Couto, e "A assistência hospitalar é dever das municipalidades", por Luiz Barbosa.

Os relatórios apresentados recuperavam muitas das discussões que atravessaram as décadas anteriores, contando com a presença das mesmas personagens e abrindo espaço para novas propostas. José de Mendonça, um dos grandes defensores da criação de hospitais públicos na cidade, usou seu espaço para conclamar ao apoio ao projeto do deputado Amaral Carvalho, de 1921, que recuperava em sua quase totalidade o Projeto Mascarenhas - à exceção do modelo arquitetônico adotado, que passava a ser o monobloco, e do nome do Hospital de Clínicas, que seria Pedro II, em homenagem ao imperador (Brasil, 1921). Outros, como Irineu Malagueta, trouxeram novamente à tona a discussão sobre a quem deveria caber a construção dos hospitais: à municipalidade ou à federação? Para Luiz Barbosa esta seria uma função do município... Miguel Couto lançou o debate público sobre a questão da gratuidade nos serviços. Foi aplaudido por José de Mendonça no que tangia à defesa da abertura de hospitais, e criticado com relação à inobservância da verificação da indigência, considerada por ele como necessária. Esse ponto levou Luiz Barbosa a defender a verificação pela prefeitura, no serviço de assistência. Já Álvaro Ozório considerou "defeituosa a socialização" dos serviços de assistência e defendeu como indispensável a criação de um seguro obrigatório contra a doença (Actas e Trabalhos, 1923).

Em 1924 José Mendonça publicou na Revista do Brasil de 1924 um artigo, posteriormente transcrito na revista Brazil-Médico do mesmo ano, no qual reiterava a proposta de construção de quatro hospitais, de mil leitos cada um. ${ }^{13}$ A concepção de organização hospitalar desse médico era fortemente inspirada na experiência austríaca. Assim, para Mendonça, nas cidades, onde os terrenos eram mais caros, deveriam se localizar hospitais destinados a atender as vítimas de acidentes (de rua e de trabalho), os prontossocorros; para os doentes "curáveis" (internações curtas), as policlínicas; e para as parturientes, as maternidades. Já no campo, onde os terrenos eram mais baratos, deveriam instalar-se as casas de convalescentes, os sanatórios para tuberculosos, os hospitais de alienados e os sanatórios para "nervosos e viciados", segundo os termos do autor. Com relação à gratuidade, propunha que fosse regulamentada uma lei que obrigasse as empresas (estatais, industriais, comerciais ou rurais) a contribuir com valores proporcionais ao número de empregados que tivessem (Mendonça, 1924). 
Nesse cenário sobressaiu o projeto de criação dos cinco hospitais na década de 1920, dois dos quais o Hospital Gaffrée \& Guinle e o Hospital do Câncer - construídos graças à ação filantrópica de Guilherme Guinle (1882-1960), empreendimentos diretamente vinculadas ao projeto de Carlos Chagas e dos médicos ligados à Inspetoria da Lepra e das Doenças Venéreas.

Os projetos do Hospital Gaffrée \& Guinle e do Hospital do Câncer tornaram-se relevantes por terem sido empreendidos em virtude da benemerência do industrial carioca Guilherme Guinle. À época, a participação da elite brasileira na construção/manutenção de hospitais/dispensários era considerada inexistente por seus contemporâneos, a ponto de a atitude de Guinle ser interpretada como "exemplar" (Sanglard, 2008). Essa exemplaridade tão divulgada na época vem corroborar as palavras de José Mendonça (1924): o médico, tempos antes, afirmara serem raras as fortunas individuais, o que inviabilizaria a participação destas em ações filantrópicas e, conseqüentemente, transformaria o governo no único agente capaz de empreender obras de tal magnitude.

Junto com esses projetos houve também a criação, em 1924, do Abrigo-Hospital Arthur Bernardes, no bairro de Botafogo, destinado à clínica e à cirurgia pediátricas e vinculado às ações da Inspetoria de Higiene Infantil, a cargo do médico Antônio Fernandes Figueira. No projeto original previa-se, além da assistência às crianças, a instalação da Maternidade da Faculdade de Medicina (Livro de ofícios, 10 jul. 1923).

Durante a presidência de Washington Luiz, foi indicativa de mudança na política pública voltada para a assistência hospitalar a criação, em 1926, da Assistência Hospitalar, órgão autônomo em relação ao DNSP, o qual tinha por incumbência a gestão dos hospitais São Francisco de Assis e Pedro II, bem como a fiscalização dos demais estabelecimentos hospitalares da capital (Brasil, 1930). A direção da Assistência Hospitalar foi entregue a João Marinho, professor da Faculdade de Medicina. O órgão contava com um conselho hospitalar, formado por Ataulfo de Paiva, Carlos Chagas, Guilherme Guinle, Clementino Fraga, Abreu Fialho e Miguel de Carvalho. Cabia a estes o assessoramento ao diretor no projeto mais ambicioso do órgão: a construção de um hospital - Hospital de Clínicas Arthur Bernardes para a Faculdade de Medicina, com capacidade para atender 1.800 pessoas (Sanglard, 2007). A construção desse hospital atendia a duplo objetivo: dotar de hospital próprio a Faculdade de Medicina do Rio de Janeiro e aumentar a disponibilidade de leitos para a cidade. Esse projeto sistematizava todos os outros que circularam ao longo dos 25 anos anteriores.

O terreno escolhido, na região da Mangueira, foi desapropriado em janeiro de 1926. Um dos atrativos da área, e uma das justificativas apresentadas para a sua escolha, era o fácil acesso da população carente, sobretudo a dos subúrbios - localizava-se na estação da Mangueira, em proximidade com a Estrada de Ferro Central do Brasil e com a Leopoldina Railway, e ao alcance de bondes e automóveis (Brasil, 1956).

Considerado pela imprensa carioca ora como um "Notável Empreendimento", ora como "iniciativa de última hora", o projeto desse hospital teve sua gestão marcada por uma série de divergências. O projeto arquitetônico já estava escolhido quando João Marinho assumiu a direção do órgão. Fora encomendado a Porto d'Ave - mesmo arquiteto responsável pelos projetos dos hospitais Gaffrée \& Guinle e do Câncer - logo após a escolha do terreno; sua pedra fundamental foi lançada a 19 de junho de 1926 (Notável empreendimento, 1926).

Para a confecção do projeto arquitetônico, Porto d'Ave contou com o assessoramento dos professores catedráticos da Faculdade de Medicina. O responsável técnico era o professor Rocha Vaz, então diretor 
da faculdade. De acordo com o plano apresentado por Rocha Vaz ao governo em junho de 1926, o Hospital de Clínicas seria construído segundo a técnica alemã, pavilhonar, mas guardaria a organização interna americana, o que diferia das últimas propostas, conforme já comentado.

Não foi fácil encontrar o consenso entre os professores da faculdade, a Assistência Hospitalar e Porto d'Ave com relação ao projeto do hospital, e eram notórias as disputas travadas entre João Marinho e Porto d'Ave, além das várias discussões entre os professores da Faculdade de Medicina - explicitadas tanto em periódicos médicos como a Folha Médica, órgão oficial da Sociedade de Medicina e Cirurgia do Rio de Janeiro, quanto na imprensa cotidiana em geral.

Entre os pontos de discórdia estava a alegada proximidade com uma grande área populosa. Contudo, vários críticos gostariam que o novo hospital fosse localizado mais próximo ao prédio da faculdade, na Praia Vermelha, a fim de facilitar a locomoção de alunos e professores; para outros, a localização deveria ser próxima ao Hospital São Francisco, o que reunia as vantagens de estar próxima ao centro da cidade e de transformar a região do Mangue em um grande pólo de saúde - ali, também, já se encontrava instalada a Faculdade de Enfermeiras Anna Nery. Este último grupo pleiteava também a construção de um novo prédio para a faculdade na região.

O certo é que em 1931 as obras do hospital foram embargadas pelo presidente Getulio Vargas e submetidas a sindicância interna. A imprensa da época, que tanto publicara críticas, elogios ou incentivos quando as obras pareciam quase paradas, não perdeu a esperança de ver edificado o projeto, mesmo quando publicou as razões alegadas pelo diretor da Assistência Hospitalar, o médico Pedro Ernesto, para solicitar o embargo da construção: os gastos desmesurados e sem controle. Em 1934 as obras do hospital foram abandonadas em definitivo. Com o passar do tempo seu esqueleto foi ocupado - originando a favela do Esqueleto -, e nos anos 70 foi ali instalada a Universidade do Estado do Rio de Janeiro.

Assim, a década de 1920 terminou sem que um dos maiores problemas da Assistência Pública tivesse sido resolvido.

\section{O Legado dos Anos 1920: assistência à saúde entre a filantropia e a ação do Estado}

O advento da República, em 1889, trouxe mudanças no campo da assistência pública e, também, um rearranjo de forças que marcou todo o período aqui abordado. Se nos primeiros anos o problema do saneamento da cidade dominou a agenda política, no segundo momento a questão da organização da assistência passou a ganhar espaço nas preocupações de médicos e filantropos.

Um dos questionamentos que perpassam todo o período diz respeito à 'competência' das ações de saúde no Distrito Federal. O ponto nevrálgico dessa discussão era a construção de hospitais "oficiais". A quem caberia a incumbência: à prefeitura ou à União? Essa pergunta atravessou todo o período, sem uma resposta definida.

É certo que a percepção dos envolvidos nas discussões foi mudando ao longo do tempo aqui delimitado. Em 1902 não se cogitava a construção de hospitais por parte dos poderes públicos. A maioria dos presentes no Congresso Nacional de Assistência Pública e Privada, em 1908, apostava que a melhor saída para a assistência pública era a união de esforços com a assistência privada - aquela que exercia uma atividade pública. Em 1916 essa idéia ainda era válida, como bem alertou Ataulfo de Paiva. Essa união 
não eliminava, contudo, a necessidade de construção de hospitais, ditos oficiais, porém apoiava-se bastante nas ações das instituições filantrópicas, notadamente as policlínicas Geral do Rio de Janeiro e de Botafogo, e o Ipai.

Esse período também foi fortemente marcado pela defesa da assistência à mulher e da assistência à infância, vinculada a uma grande preocupação com o futuro da nação, na medida em que as crianças eram consideradas como tal. As instituições voltadas para as mulheres, por sua vez, apresentavam uma preocupação com a mãe-mulher, sobretudo com as operárias, e os meios de lhes garantir condições de cuidar de seus filhos e retornar ao trabalho. Em ambas as formas de assistência o puerpério e a puericultura estavam intimamente ligados.

Foi com esses princípios que se criaram diversas instituições filantrópicas voltadas para esse público: o já citado Ipai, instituição filantrópica voltada para as campanhas de educação e assistência maternoinfantil, fortemente inspirada em organizações francesas como as Gouttes de Lait; a Policlínica das Crianças (1909) e o Hospital São Zaccharias (1916), ambos criados e mantidos pela Santa Casa da Misericórdia e destinados, respectivamente, às crianças das zonas Norte e Sul da cidade, e com objetivos muito semelhantes aos do Ipai; e a Pro Matre (1918), maternidade filantrópica voltada para a mulher pobre. Em todas essas instituições, médicos e filantropos se uniram em prol da assistência à mulher e à criança. No mesmo período também foi criada a Maternidade de Laranjeiras, inicialmente como instituição privada, com atuação filantrópica, e depois como instituição semi-oficial, ao se tornar MaternidadeEscola da Faculdade de Medicina, em 1918.

Outro ponto a ser observado é que muitas dessas instituições voltadas para o atendimento da mãe e da criança se localizavam nos subúrbios da cidade, onde, seguindo a expansão da urbe, vivia a população operária. Foi nos subúrbios do Rio de Janeiro que se instalaram as instituições filantrópicas, mantidas por personagens de importância no meio político e industrial carioca e por associações benevolentes. Bairros como São Cristóvão e Cascadura foram objeto da atenção desses filantropos.

A partir de 1918 o discurso mudou. Não era mais o encontro da filantropia com as políticas públicas que estava sendo defendido e difundido pelos médicos, mas sim a criação e a construção de hospitais pelo poder público, pela União. Carlos Chagas deixou isso claro no discurso já citado de 1918, assim como os diversos artigos publicados por José de Mendonça sobre o tema e as discussões na Câmara dos Deputados acerca da construção de hospitais no Rio de Janeiro. Sobretudo notou-se uma união maior dos médicos em torno da questão e que a atuação da União na abertura de hospitais não devia restringirse ao Distrito Federal. Este último ponto pode ser verificado no Congresso de Práticos de 1922 e mesmo no discurso do médico e deputado Antônio Austregésilo (Actas e Trabalhos, 1923; Brasil, 1923).

Contudo, a transformação dos pleitos em realidade foi bem mais difícil. Carlos Chagas, como diretor do DNSP, esteve à frente da criação de seis hospitais e duas colônias: três adaptados em prédios já existentes (Pedro II, 1920, São Francisco de Assis, 1922, e Abrigo-Hospital Arthur Bernardes, 1924); dois construídos graças à benemerência da família Guinle (Gaffrée \& Guinle, 1924-1929, e do Câncer, inacabado); o Hospital das Clínicas da Faculdade de Medicina (mal começado) e as colônias Juliano Moreira (1924), para alienados, e de Curupaity (1922-1928), para leprosos. Desses, cinco estavam diretamente vinculados às políticas públicas postas em prática naquele momento: o Abrigo-Hospital, vinculado à Inspetoria de Higiene Infantil; os dois financiados pelos Guinle e a Colônia de Curupaity, 
subordinados à Inspetoria de Profilaxia da Lepra e das Doenças Venéreas; e a Colônia Juliano Moreira, para o atendimento de psicopatas.

Não resta dúvida de que na década de 1920 houve um avanço na organização da assistência pública na capital federal, mas apesar de os discursos chamarem o governo à responsabilidade pela assistência hospitalar na cidade, o recurso à filantropia se mostrou a solução viável e ideal para a expansão dos socorros médicos. O período foi também marcado pelo surgimento de diversos hospitais vinculados às sociedades beneficentes (Hospital Evangélico, Beneficência Espanhola, Hospital Albert Sabin e Amparo Feminino) que, ao atenderem gratuitamente os seus sócios, exerciam uma função pública, concorrendo assim para desonerar as enfermarias da Santa Casa. E viu surgirem medidas visando à criação de uma previdência social no Brasil, como resposta às greves operárias ocorridas em 1917 e 1918, no Rio de Janeiro e em São Paulo (Oliveira \& Teixeira, 1986). A preocupação com a saúde do trabalhador começou a se fazer presente nos discursos dos médicos, nas propostas, entre outras, de custeio da hospitalização dos operários, nos hospitais públicos, por parte das empresas (Mendonça, 1924).

Por fim, no período aqui abordado é de se notar a mudança ocorrida no discurso dos médicos: a publicação da obra Assistência Pública e Privada no Rio de Janeiro (1922) foi o último libelo sobre um padrão de assistência liberal. Desde o início da década, e cada vez mais, clamava-se pela presença do Estado na solução e direção da assistência no Rio de Janeiro. Contudo, o governo ainda usou a filantropia como recurso para a organização da assistência hospitalar, mesmo que, no caso das ações de Guilherme Guinle na saúde, ela representasse, antes de tudo, um apoio e um investimento na política de Carlos Chagas, na medida em que a família Guinle financiou os projetos da Inspetoria de Profilaxia da Lepra e das Doenças Venéreas, onde a manutenção dos hospitais estava a cargo do DNSP.

Foi apenas na década de 1930 que a construção e a manutenção de hospitais por toda a cidade se tornaram uma política de Estado, implementada por duas esferas de poder: a municipal e a federal. Mas tratava-se de uma outra conjuntura política.

\footnotetext{
Notas

${ }^{1}$ Em um tempo em que os preceitos de higiene ganhavam força, a intervenção das autoridades passou a ter papel decisivo, sobretudo nos locais conhecidos como focos privilegiados da doença: prisões, portos, barcos e hospitais gerais. Nesse novo quadro o hospital tradicional perdeu espaço. Foi preciso transformá-lo tanto física como conceitualmente, eliminando sua feição assistencial em benefício da terapêutica.

${ }^{2}$ Esta Lei dos Pobres, fortemente inspirada nas teorias higienistas do final do século XVIII, baseava-se no entendimento de que nos bolsões de pobreza londrinos estavam os focos das principais epidemias, o que justificava as medidas de intervenção sanitárias nessas localizações. A sujeira, a falta de drenagem dos pântanos e a ausência de esgotamento sanitário foram os principais problemas assinalados, e como solução adotou-se a instalação de encanamento que levava água potável para todas as cidades, bem como uma rede de esgoto, que desaguava para longe do perímetro urbano as águas servidas (Bourdelais, 2003).

${ }^{3}$ Esse hospital, posteriormente chamado de Hospital Paula Candido, destinava-se ao isolamento dos marítimos (imigrantes e marinheiros) acometidos de doenças contagiosas. Localizava-se em Jurujuba, Niterói, e foi extinto no século XX.

${ }^{4}$ Os cortiços eram considerados, desde o Império, como lugar da desordem e do contágio, e foram inúmeras as tentativas de destruílos ou impedir que fossem construídos. Contudo, a questão da propriedade privada - tão cara ao Império, pois poderia abrir um precedente no que tange à posse do escravo - impedia que as demolições ocorressem; quanto à fiscalização, sempre se encontrava uma forma de burlá-la (Chalhoub, 2004).
} 
${ }^{5}$ A Constituição de 1891 transferiu aos estados a gestão da saúde. No caso do Distrito Federal, coube à prefeitura a gestão e organização dos serviços. Assim foi criada, em 1893, a Diretoria-Geral de Higiene e Assistência Pública da cidade do Rio de Janeiro, com o objetivo de organizar, dirigir e distribuir, na cidade, os serviços de socorro médico gratuito - tanto em épocas 'normais' quanto epidêmicas - e o atendimento no caso de acidentes e desastres nos locais públicos, entre outros (Barbosa, 1908).

${ }^{6}$ Por exemplo, os franceses se sentiam atrasados nessa discussão em relação a seus vizinhos; a Inglaterra vinha discutindo a questão desde o início do século XIX, o que culminou com a reforma da Lei dos Pobres, e em Portugal o liberalismo passou a ser adotado desde o retorno de d. Pedro ao Reino. Data de 1834 a passagem do Hospital São José, o mais antigo de Lisboa, para o controle governamental, e de 1851 a ruptura definitiva do governo português com a Irmandade da Misericórdia.

${ }^{7}$ Eram estes os hospitais 'privados': os mantidos por irmandades e ordens terceiras; a Maternidade de Laranjeiras, de caráter semioficial; o Asilo São Luís; a Liga Brasileira contra a Tuberculose e as policlínicas Geral do Rio de Janeiro e de Botafogo.

${ }^{8}$ As 'rodas' eram o local onde se colocavam as crianças abandonadas, para que fossem levadas para o interior da instituição que as abrigava - no caso do Rio de Janeiro, a Casa dos Expostos (ou da Roda) da Santa Casa da Misericórdia, hoje Educandário Romão Duarte. Seu mecanismo de funcionamento permitia que a identidade da mãe ficasse preservada. Sua função era tentar salvar as crianças abandonadas - ou expostas - por meio do aleitamento por amas-de-leite e da educação, para que pudessem ser integradas à sociedade (Gandelman, 2001).

${ }^{9}$ Tais bases seriam: assistência à infância - menores abandonados e delinqüentes; puericultura; assistência à velhice; assistência à mulher; assistência aos estrangeiros; assistência pelo trabalho - a mendicidade profissional (questão penal); patronatos; assistência em domicílio e assistência hospitalar; assistência aos alienados; assistência aos tuberculosos; assistência aos leprosos, aos alcoólatras, aos sifilíticos; assistência metódica - meios práticos para obter uma aliança entre a assistência pública e a assistência privada; o problema no Brasil.

10 Jacques Tenon, arquiteto francês que lançou as bases do novo hospital francês, em 1788 (cf. cap. 5).

11 O DNSP foi criado em 1919 e regulamentado no ano seguinte. Era formado por uma Diretoria-Geral e três diretorias - a de Serviços Sanitários Terrestres na capital federal, a de Defesa Sanitária Marítima e Fluvial e a de Saneamento e de Profilaxia Rural -, além de dez inspetorias especiais, entre as quais as de Engenharia Sanitária; Profilaxia da Tuberculose; Estatística Demógrafo-Sanitária; Fiscalização do Exercício da Medicina, Farmácia, Arte Dentária e Obstetrícia; Profilaxia da Lepra e Moléstias Venéreas; Profilaxia Marítima (Hochman, 1998).

12 Foram financiados pela família Guinle os hospitais Gaffrée \& Guinle e do Câncer, atual Hospital Municipal Barata Ribeiro.

${ }^{13}$ Vale ressaltar que as bases do Projeto Mascarenhas haviam sido defendidas, em 1923, no editorial da revista Brazil-Médico.

\section{Referências}

ABREU, L. (Ed.) Igreja, Caridade e Assistência na Península Ibérica (sécs. XVI-XVIII). Évora: Edições Colibri, Cidehus/Universidade de Évora, 2004.

ACTAS e Trabalhos do Primeiro Congresso Nacional dos Práticos: em comemoração do centenário do Brasil. Rio de Janeiro: Publicações Scientíficas, 1923.

ALLAIN, E. Rio de Janeiro: quelques données sur la capitale et sur l'administration du Brésil. Paris, Rio de Janeiro: L. Firenze et Cie Éditeurs, Lachaud et Cie, 1886.

ALMEIDA, G. Assistência Hospitalar: memória apresentada ao Congresso Nacional de Assistência Pública e Privada do Rio de Janeiro. Rio de Janeiro: Typographia Jornal do Commercio, 1908.

ASSISTÊNCIA Pública e Privada no Rio de Janeiro (Brasil): história e estatística. Rio de Janeiro: Prefeitura do Distrito Federal, 1922.

BARBOSA, L. Serviços de Assistência no Rio de Janeiro. Rio de Janeiro: Typographia Ao Luzeiro, 1908.

BENCHIMOL, J. Pereira Passos: um Haussmann tropical. Rio de Janeiro: Secretaria Municipal de Cultura, Turismo e Esportes/Departamento Geral de Documentação e Informação Cultural, 1992. (Biblioteca Carioca)

BENCHIMOL, J. (Coord.) Febre Amarela: a doença e a vacina, uma história inacabada. Rio de Janeiro: BioManguinhos, Editora Fiocruz, 2001.

BOURDELAIS, P. Les logiques du développement de l’hygiène publique. In: BOURDELAIS, P. (Dir.) Les Higiénistes, Enjeux, Modèles et Pratiques (XVIII $-X X^{e}$ siècles). Paris: Belin, 2001. 
BOURDELAIS, P. Les Épidemies Terrassées: une histoire des pays riches. Paris: Éditions de la Martinière, 2003.

BOURDELAIS, P. Les bureaux d'hygiène municipaux (1879-1900): connaître, décider, innover, assister, convaincre e diffuser. In: BOURDELAIS, P. \& FAURE, O. Les Nouvelles Pratiques de Santé, XVIII ${ }^{e}-X X^{e}$ Siècles. Paris: Belin, 2005.

BRASIL. Anais da Câmara dos Deputados. Rio de Janeiro: Imprensa Nacional, 1920.

BRASIL. Anais da Câmara dos Deputados. Rio de Janeiro: Imprensa Nacional, 1921.

BRASIL. Anais da Câmara dos Deputados. Rio de Janeiro: Imprensa Nacional, 1923.

BRASIL. Mensagens ao Congresso: Washington Luis P. de Sousa. Rio de Janeiro: Imprensa Nacional, 1930.

BRASIL. Mensagens ao Congresso: obras completas de Epitácio Pessoa. Rio de Janeiro: INL, 1956. v. XVII.

CHAGAS, C. Discurso do Dr. Carlos Chagas no banquete offerecido pela classe medica do Rio de Janeiro, no Edifício do Derby-Club, em homenagem aos medicos bahianos, em 9 de dezembro de 1918. Rio de Janeiro: Typ. Jornal do Commercio, de Rodrigues, 1919. Biblioteca Virtual Carlos Chagas <www4.prossiga.br/chagas/>. Acesso em: 2 maio 2003.

CHALHOUB, S. Cidade Febril: cortiços e epidemias na corte imperial. 3. ed. São Paulo: Companhia das Letras, 2004. CORBAIN, A. Le Miasme et la Jonquille. Paris: Flammarion, 1986.

DUPRAT, C. Pour l'Amour de l'Humanité - Le Temps des Philantropes: la philantropie parisienne des Lumières à la monarchie de Julliet. Paris: Éditions CTHS, 1993. t. 1.

DUPRAT, C. Usage et Pratiques de la Philantropie: pauvreté, action sociale et lien social, à Paris, au cours du premier XIX ${ }^{e}$ sciècle. Paris: Comité d'Histoire de la Sécurité Sociale, 1996. v. 1 et 2.

FAURE, O. Les Français et leur Médecine aux XIX' Siècle. Paris: Belin, 1993.

FIGUEIRA, A. Reforma dos hospitais. Brazil-Médico, 15 ago. 1902, p. 311-312.

FIGUEIRA, A. Assistência pública: assistência à infância e particularmente o que se refere às medidas a adotar contra a mortalidade infantil. Educação das crianças deficientes. Relatório apresentado ao Congresso Nacional de Assistência Pública e Privada. Brazil-Médico, 1 e 8 nov. 1908, p. 401-405, 411-415, 419-420.

GANDELMAN, L. M. A Santa Casa da Misericórdia do Rio de Janeiro nos séculos XVI a XIX. História, Ciência, Saúde - Manguinhos, 8(3): 613-630, dez. 2001.

GOMES, A. Burguesia e Trabalho. Rio de Janeiro: Editora Campus, 1979.

HOCHMAN, G. A Era do Saneamento. São Paulo: Hucitec, Anpocs, 1998.

HORNE, J. Le Musée Social: aux origines de l'État providence. Paris: Belin, 2004.

LIVRO de ofícios da Faculdade de Medicina do Rio de Janeiro para o ano de 1923. (Mimeo.)

MENDONÇA, J. Assistência hospitalar no Rio de Janeiro. Correio da Manhã, 14 jun. 1920, p. 2.

MENDONÇA, J. A organização econômica do hospital moderno. Revista do Brasil, XXVI(101): 8-15, maio 1924.

MONCORVO FILHO. Assistência pública no Rio de Janeiro e particularmente da assistência à infância. Comunicação enviada ao IV Congresso Internacional de Assistência Pública e Privada, realizado em Milão em 1906. Rio de Janeiro: Imprensa Nacional, 1907.

NOTÁVEL empreendimento - Hospital de Clínicas 'Arthur Bernardes', o lançamento de sua pedra fundamental (1926). Vida Doméstica - Revista da Família e da Mulher, 101, jul. 1926.

OLIVEIRA, J. \& TEIXEIRA, S. (Im)Previdência Social: 60 anos de história da previdência social no Brasil. Petrópolis, Rio de Janeiro: Vozes, Abrasco, 1986.

PAIVA, A. Justiça e Assistência. Rio de Janeiro: Typographia do Jornal do Commercio, 1916.

POLANYI, K. A Grande Transformação: as origens da nossa época. São Paulo: Campus, 2000.

SANGLARD, G. Da Misericórdia ao Estado: questões de saúde no Brasil na primeira metade do século XX. In: PRIEGO, N. \& LOZANO, S. (Orgs.) Paradigmas, Culturas y Saberes: la transmisión del conocimiento científico a Latinoamérica. Madrid: Editorial Iberoamericana, 2007.

SANGLARD, G. Entre os Salões e o Laboratório: Guilherme Guinle, a saúde e a ciência no Rio de Janeiro. Rio de Janeiro: Editora Fiocruz, 2008. (Col. História \& Saúde) 


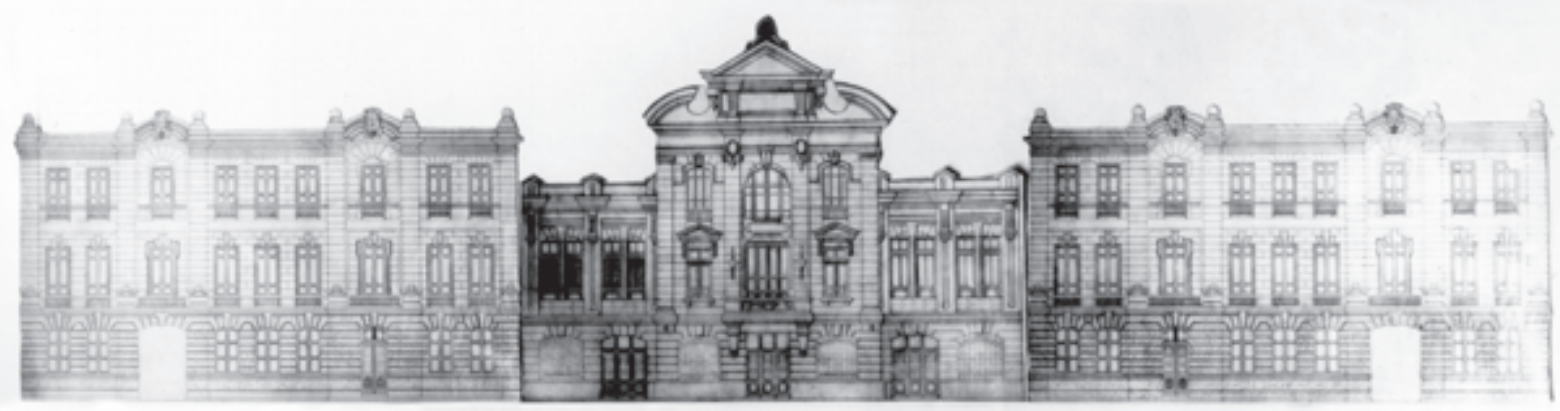

Posto Central de Assistência, [s.d.]. Acervo Arquivo Geral da Cidade do Rio de Janeiro

O pronto-socorro municipal foi inaugurado em 1907, na rua Camerino. Em 1910 o atual Hospital Municipal Souza Aguiar foi transferido para a praça da República, onde permanece até hoje em conjunto arquitetônico dos anos 1970.

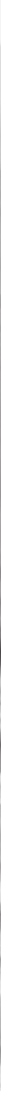

Vista aérea do Instituto Oswaldo Cruz, [1920]. Acervo Casa de Oswaldo Cruz

Nesta foto percebe-se o Núcleo Arquitetônico Histórico da Fundação Oswaldo Cruz, formado pelo Pavilhão Mourisco, o Quinino, a Cavalariça, o Pavilhão do Relógio (ou Pavilhão da Peste) e o Aquário, este já destruído. A arquitetura neomourisca singulariza o castelo não apenas em relação às demais construções do conjunto, mas como um dos mais destacados edifícios civis construídos para a saúde no início do século XX no Rio de Janeiro. 


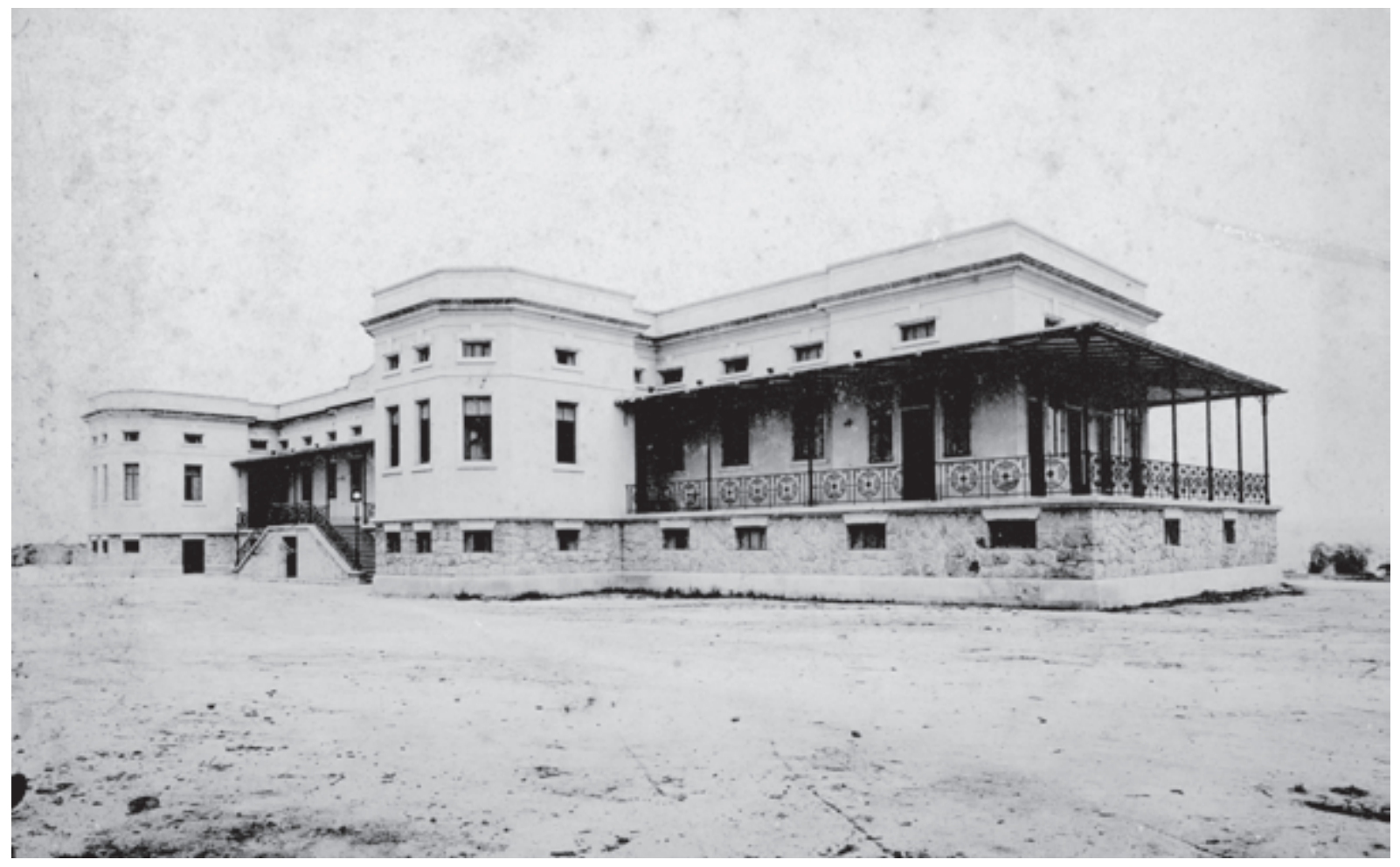

Hospital Oswaldo Cruz, [s.d.]. Acervo Casa de Oswaldo Cruz

Este é o único dos seis pavilhões projetados por Luiz Moraes Jr., entre 1912 e 1917, para o Hospital Oswaldo Cruz, hoje Hospital Evandro Chagas. Sua inauguração em 1918 enfatiza a importância do estudo das grandes endemias para a instituição.

\begin{abstract}
Hospital do Amparo Feminino, [s.d.]. Acervo particular

O Hospital do Amparo Feminino, inaugurado em 1924, era mantido pela Associação das Senhoras

Evangélicas para dar assistência materno-infantil às mulheres carentes da colônia alemã e contava com maternidade e berçário. Nos anos 1960 a instituição ganhou um outro edifício com características arquitetônicas próximas às do art déco.
\end{abstract}

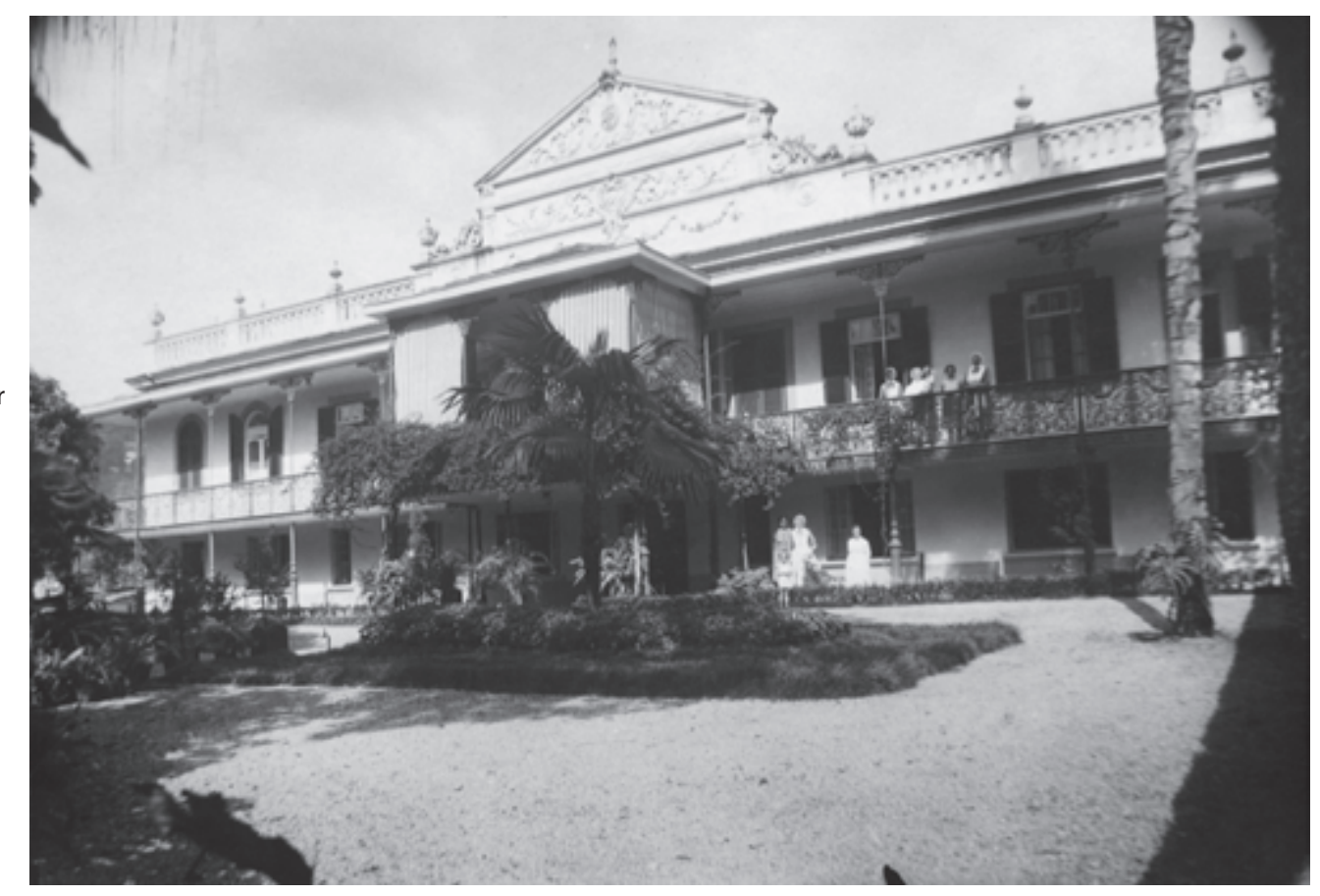


A Primeira República e a Constituição de uma Rede Hospitalar...

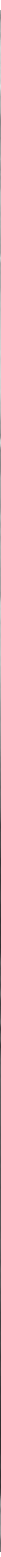

Perspectiva do projeto do Hospital e Instituto do Câncer na Mangueira, [1927]. Acervo Casa de Oswaldo Cruz, Coleção Porto d'Ave

As obras deste conjunto foram, destinadas à construção de um Hospital e Instituto do Câncer, financiados pela família Guinle, iniciaram-se em 1927 e foram abandonadas em 1936, quando as instalações foram doadas à prefeitura, que lá estabeleceu o Hospital Barata Ribeiro. 


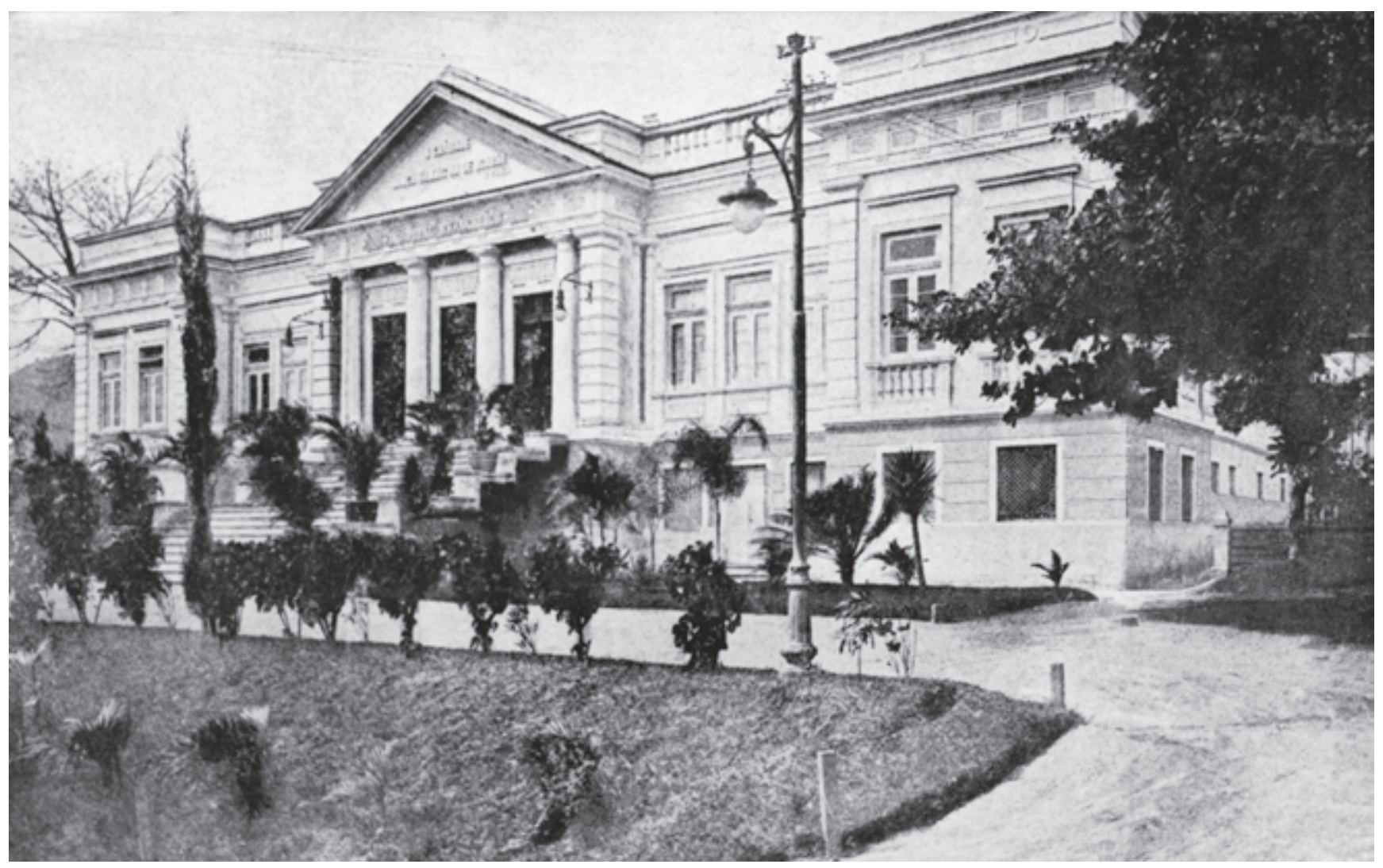

Fachada principal do Hospital Evangélico, [s.d.]. Acervo Hospital Evangélico

O Hospital Evangélico foi criado para dar atendimento médico à colônia alemã no Rio de Janeiro no final do século XIX e inaugurado em 1912. O prédio mantém-se inalterado, e nos anos 1970 o hospital ganhou um edifício de três andares. Encontra-se atualmente em fase de expansão.

Perspectiva geral do Hospital

Gaffrée \& Guinle, [1924-1929]. Acervo Casa de Oswaldo Cruz, Coleção Porto d'Ave

Hospital construído pela família Guinle para o tratamento e profilaxia da sífilis e de outras doenças venéreas. Na década de 1966 um acordo entre a Fundação Gaffrée e Guinle e o governo federal passou a responsabilidade pelo hospital para a alçada federal e o transferiu para a Faculdade de Medicina e Cirurgia do Rio de Janeiro, hoje Universidade Federal do Estado do Rio de Janeiro (UniRio).

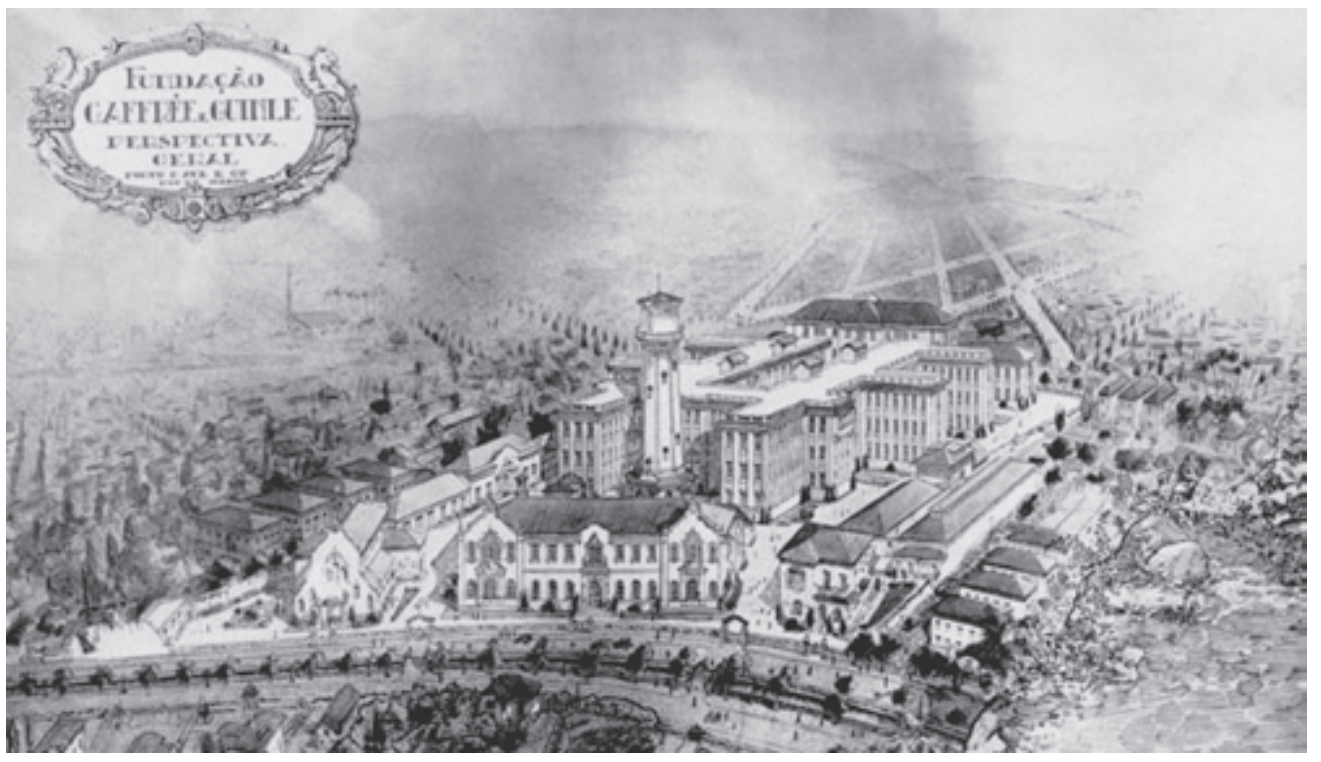


A Primeira República e a Constituição de uma Rede Hospitalar...

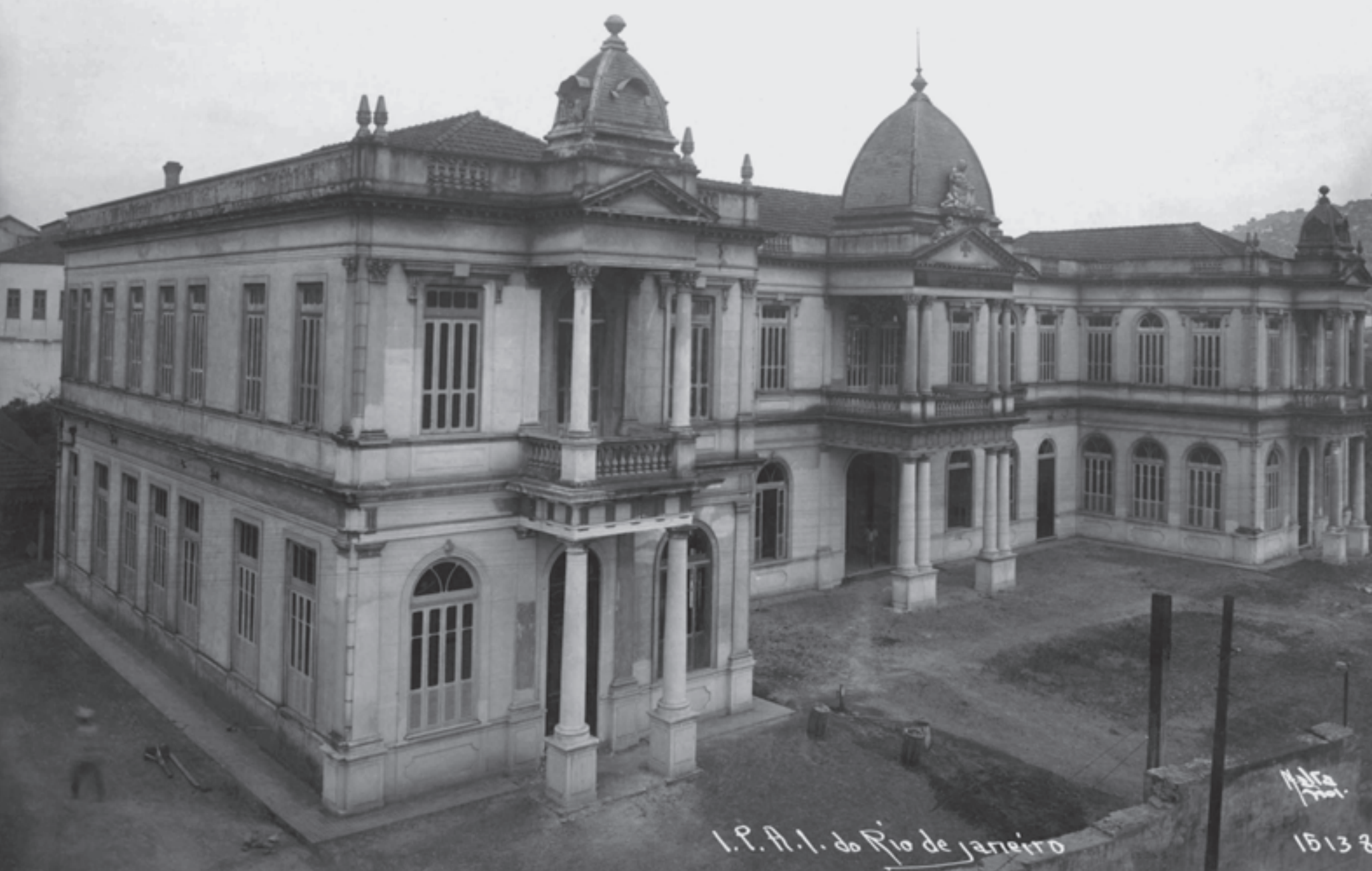

Instituto de Proteção e Assistência à Infância (Ipai) ainda em construção, [s.d.]. Foto Augusto Malta. Acervo Museu da Imagem e do Som, RJ

O Instituto de Proteção e Assistência à Infância foi criado em 1889 pelo médico Arthur Moncorvo Filho e transferiu-se para este prédio em 1914. Atualmente abriga o Instituto de Ginecologia da Faculdade de Medicina da UFRJ e, em prédio anexo construído na década de 1960, o Instituto Estadual de Diabetes e Endocrinologia Luiz Capriglione (lede). 


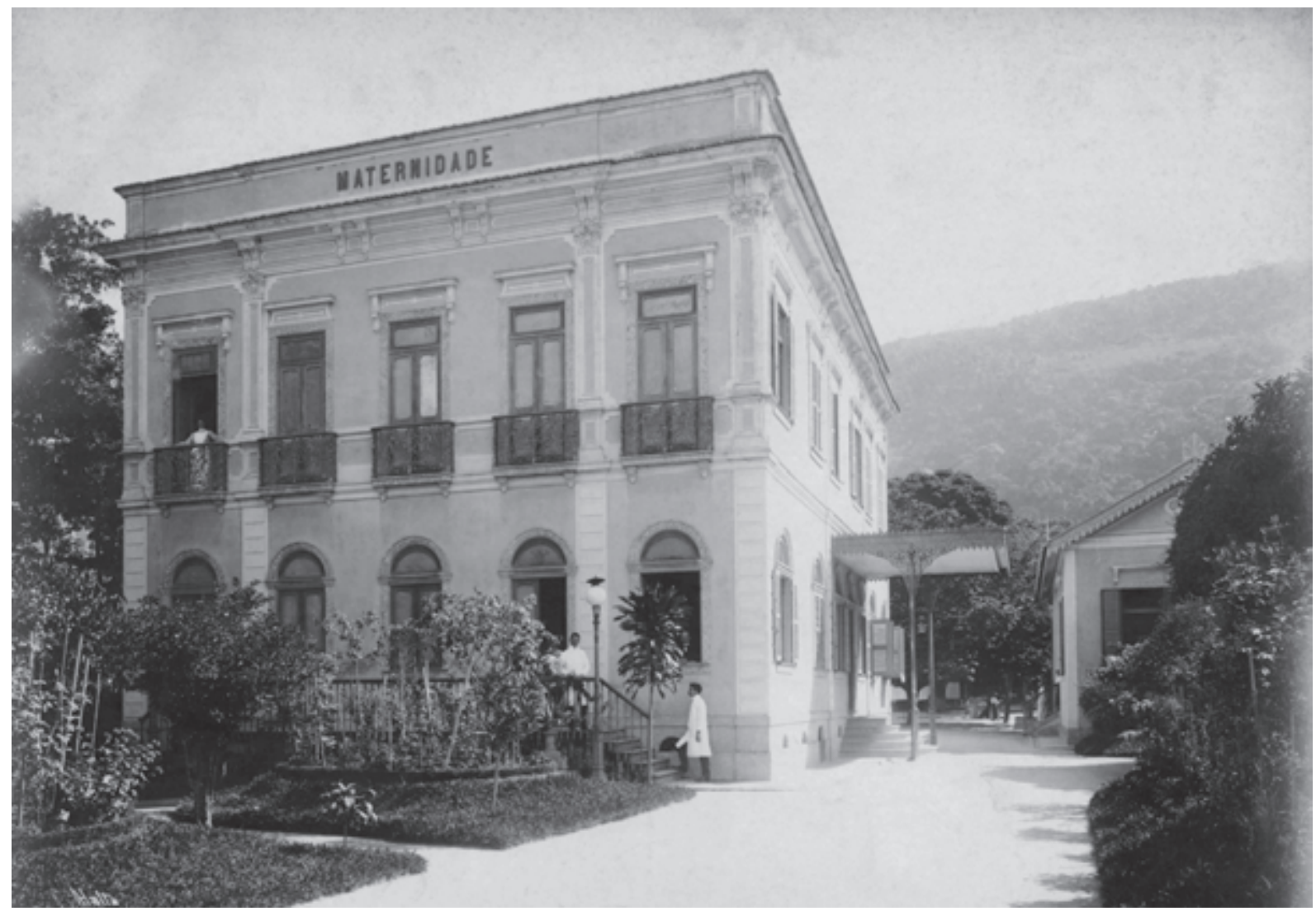

Maternidade de Laranjeiras, [s.d.]. Acervo Museu da Imagem e do Som, RJ

A Maternidade-Escola da UFRJ, criada em 1904, foi instalada em um palacete da rua das Laranjeiras que a abriga até hoje, apesar de completamente descaracterizado. Criada como instituição filantrópica, foi incorporada à Faculdade de Medicina em 1918, que lá instalou a cátedra de obstetrícia.

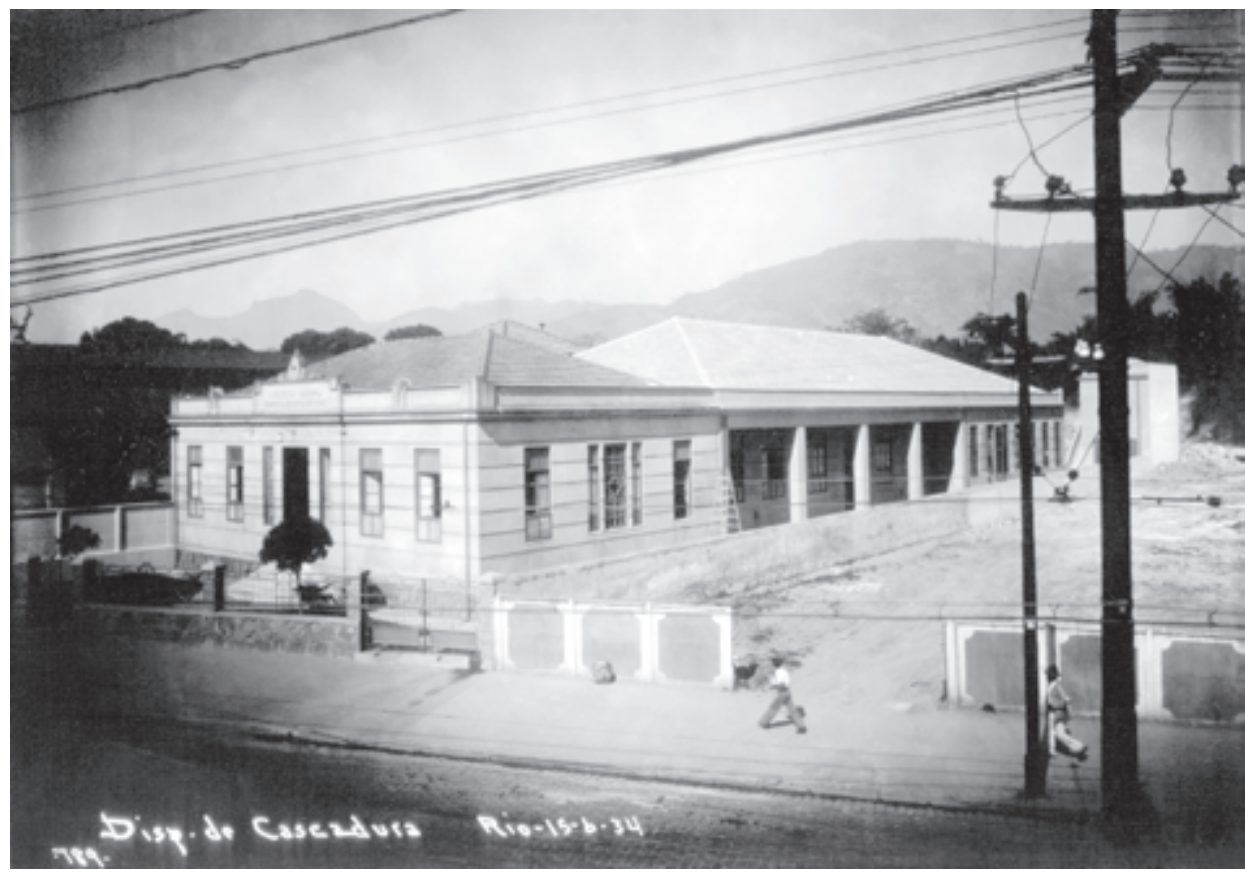

Dispensário de Cascadura, 1934. Foto Augusto Malta. Acervo Arquivo Geral da Cidade do Rio de Janeiro

O Dispensário de Cascadura remonta à criação, em 1926, de uma maternidade filantrópica (Maternidade de Cascadura ou Suburbana) doada, em 1933, à prefeitura, que lá instalou o dispensário e ampliou suas instalações. Mantém sua vocação para o cuidado da gestante, com o nome de Hospital-Maternidade Herculano Pinheiro. 


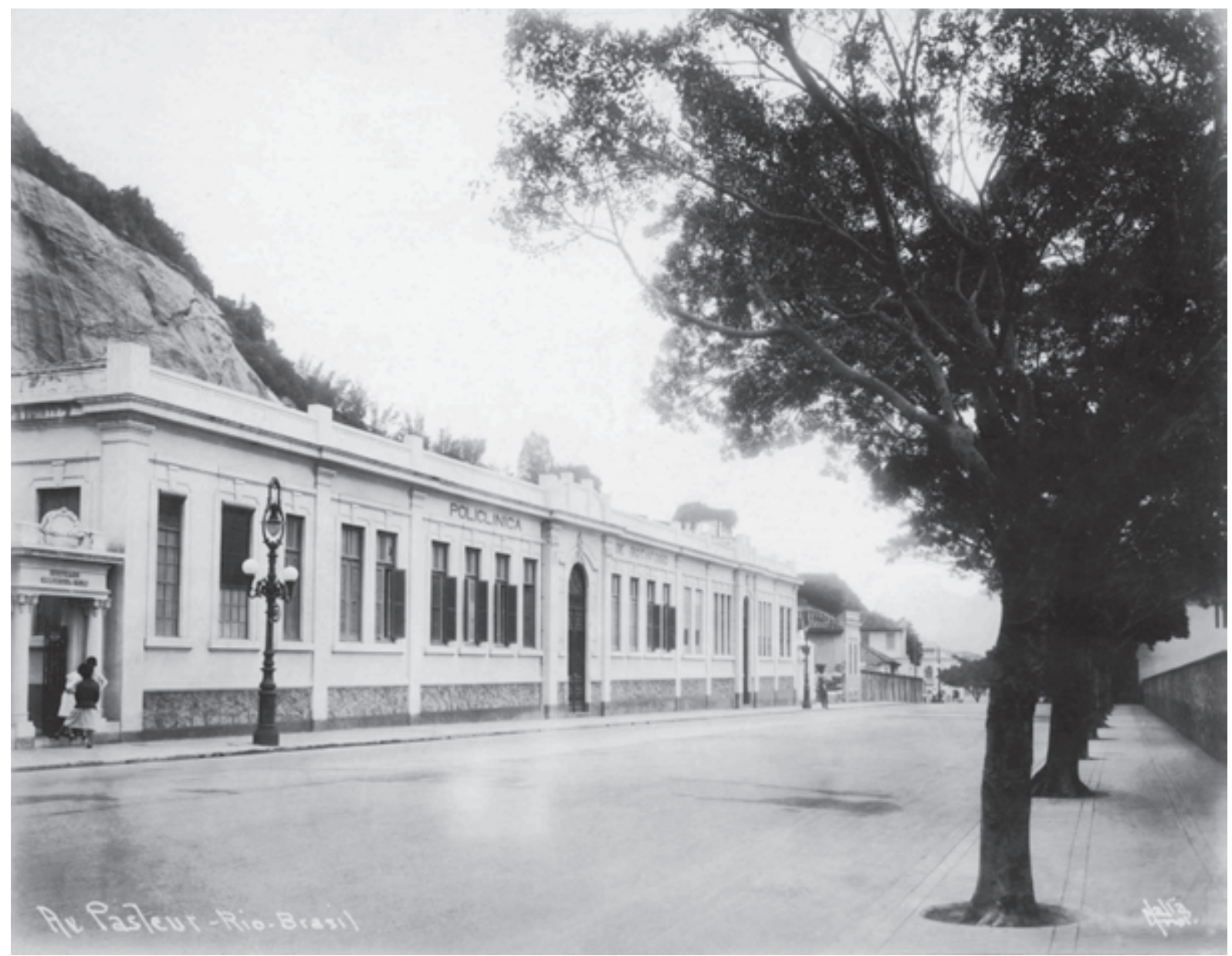

Fachada da Policlínica de Botafogo, [1922]. Foto Augusto Malta. Acervo Museu da Imagem e do Som, RJ

O prédio da Policlínica de Botafogo foi inaugurado em 1922 e é a segunda sede da instituição. A policlínica foi criada pelo médico Luiz Barbosa em fins de 1899 e iniciou seus atendimentos em junho de 1900. Sua marca mais forte era a atuação paroquial, restrita aos moradores de Botafogo e adjacências.

Sede da Diretoria-Geral de Saúde Pública, [s.d.]. Fonte: Arquivos de Higiene Este prédio foi construído na década de 1910 para abrigar a Diretoria-Geral da Saúde Pública, órgão vinculado ao Ministério da Justiça e Negócios Exteriores, responsável pelas ações de saúde pública no Distrito Federal. Atualmente integra o patrimônio do Instituto Nacional de Câncer (INCa).

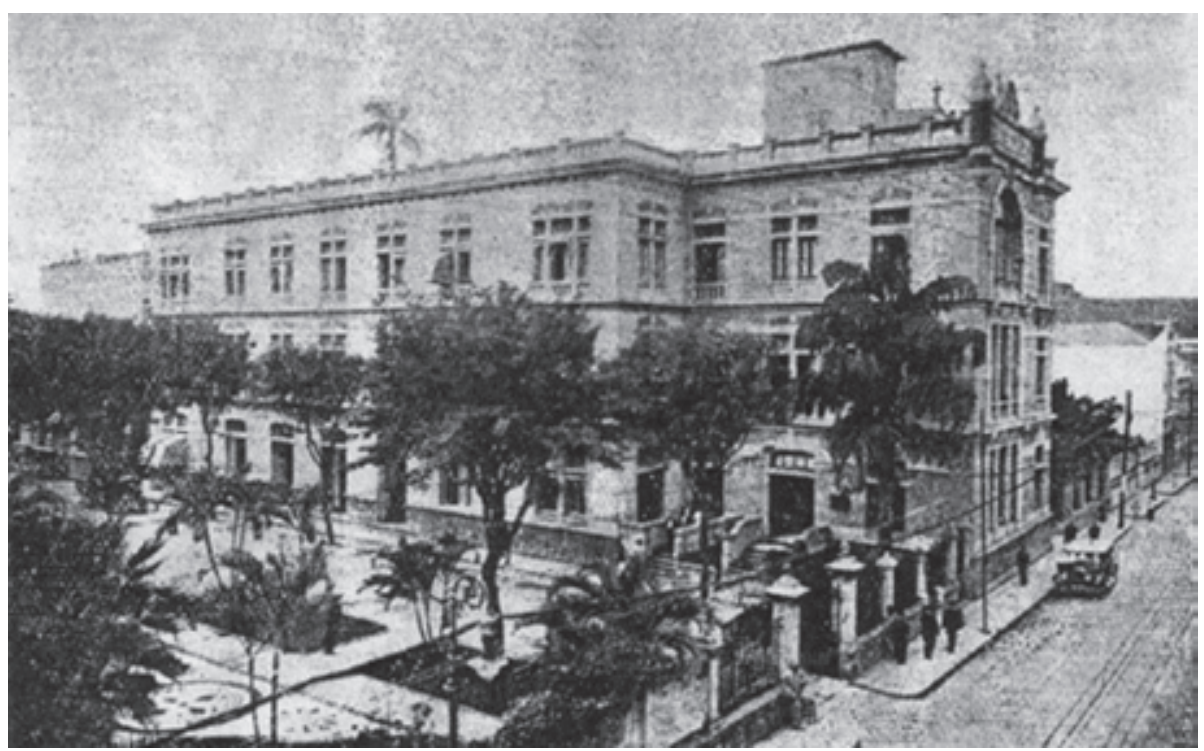




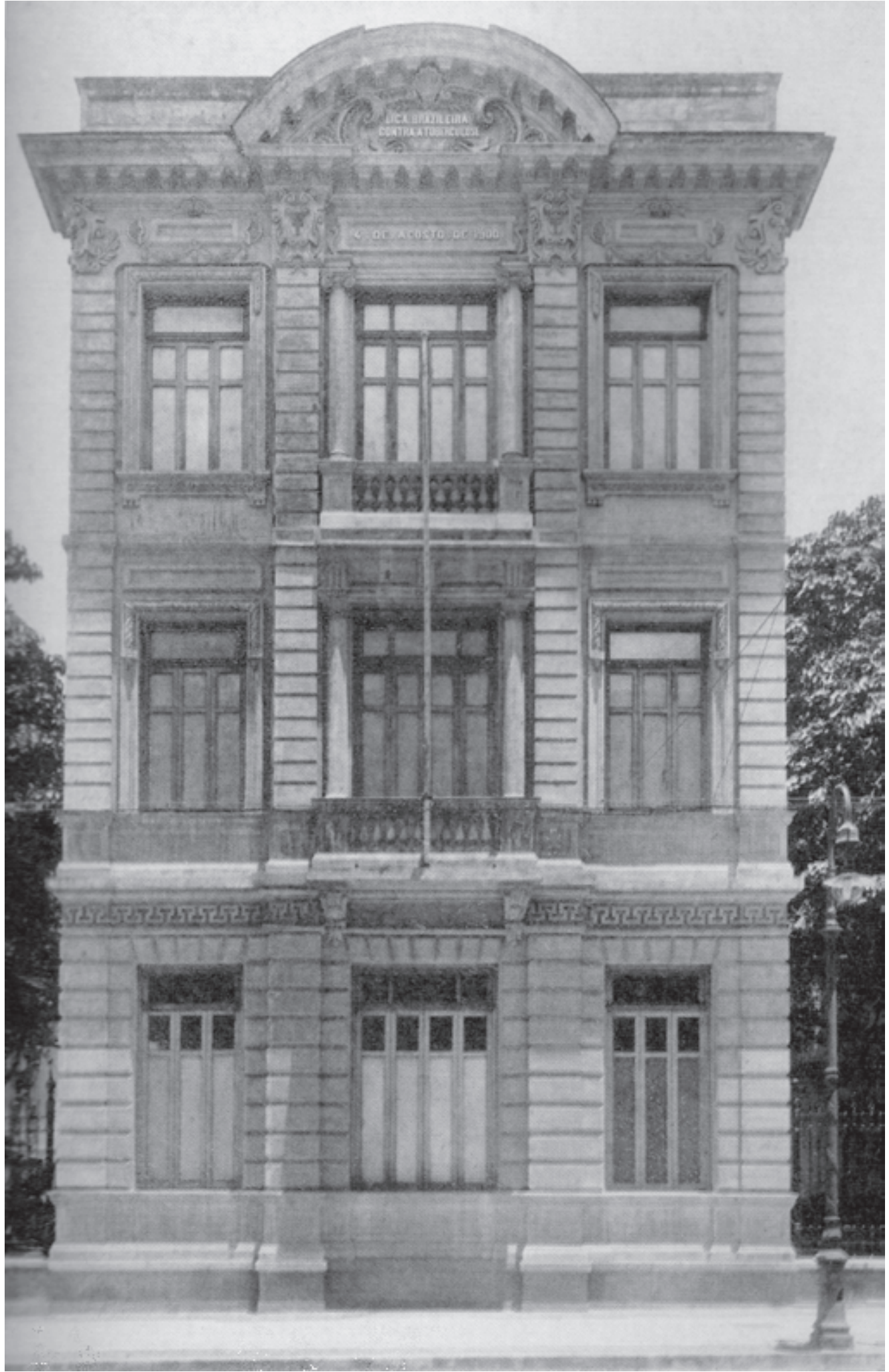

Dispensário

Azevedo Lima e sede da Liga,

1901. Acervo

Fundação Ataulfo de Paiva

Prédio

emblemático da

campanha contra a

tuberculose no Rio

de Janeiro,

construído pela

Liga Brasileira

contra a

Tuberculose em

1901. Apesar de

ter sido destruído

para abrigar um

arranha-céu da

Fundação Ataulfo de Paiva, o edifício

é simbólico do trabalho desta instituição. 
A Primeira República e a Constituição de uma Rede Hospitalar...

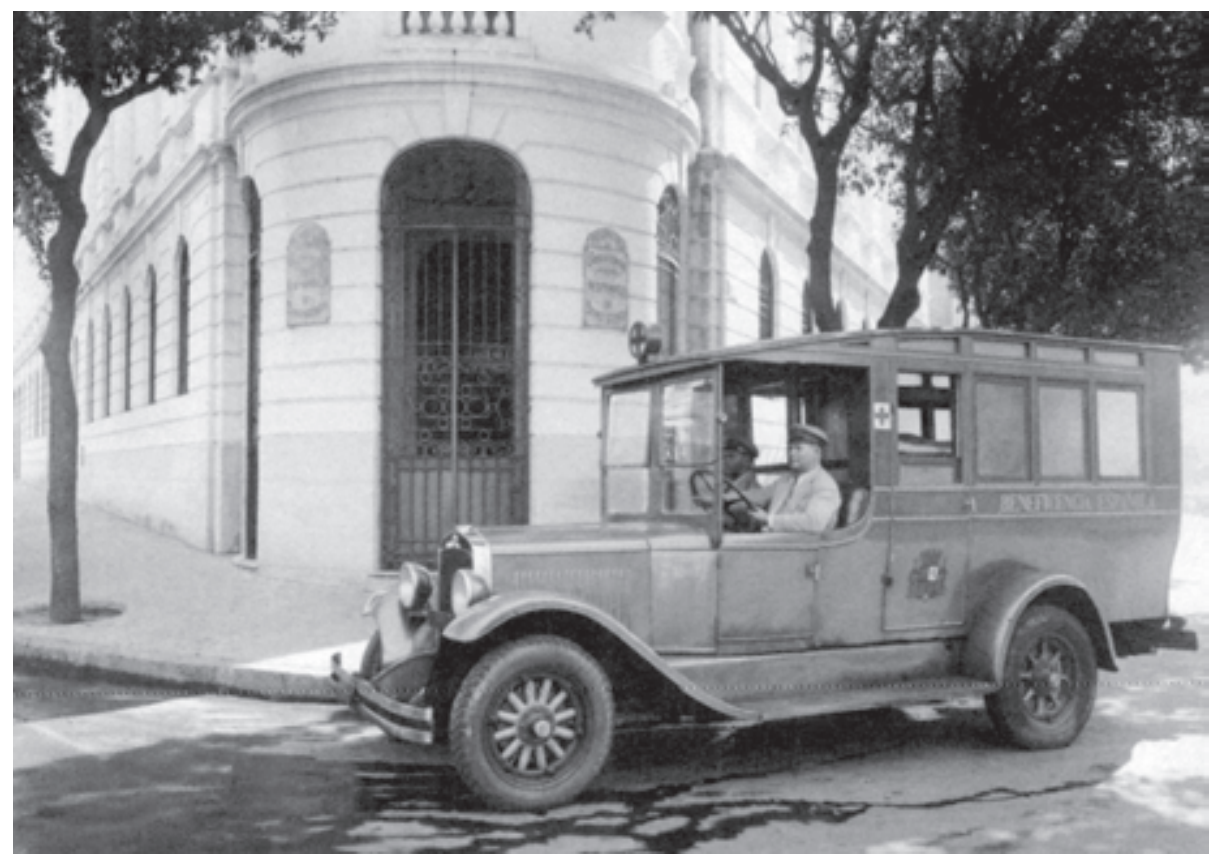

Fachada da antiga entrada principal do Hospital

Espanhol, com ambulância da Sociedade de

Beneficência à frente, [1930]. Acervo Sociedade Espanhola de Beneficência

Em 1927 a Sociedade de Beneficência Espanhola consegue, enfim, oferecer atendimento médicohospitalar para a colônia espanhola, após adquirir o prédio da antiga Casa de Saúde do Dr. Crissiúma, onde foi instalado o hospital. Desde então o prédio sofreu diversas modificações.

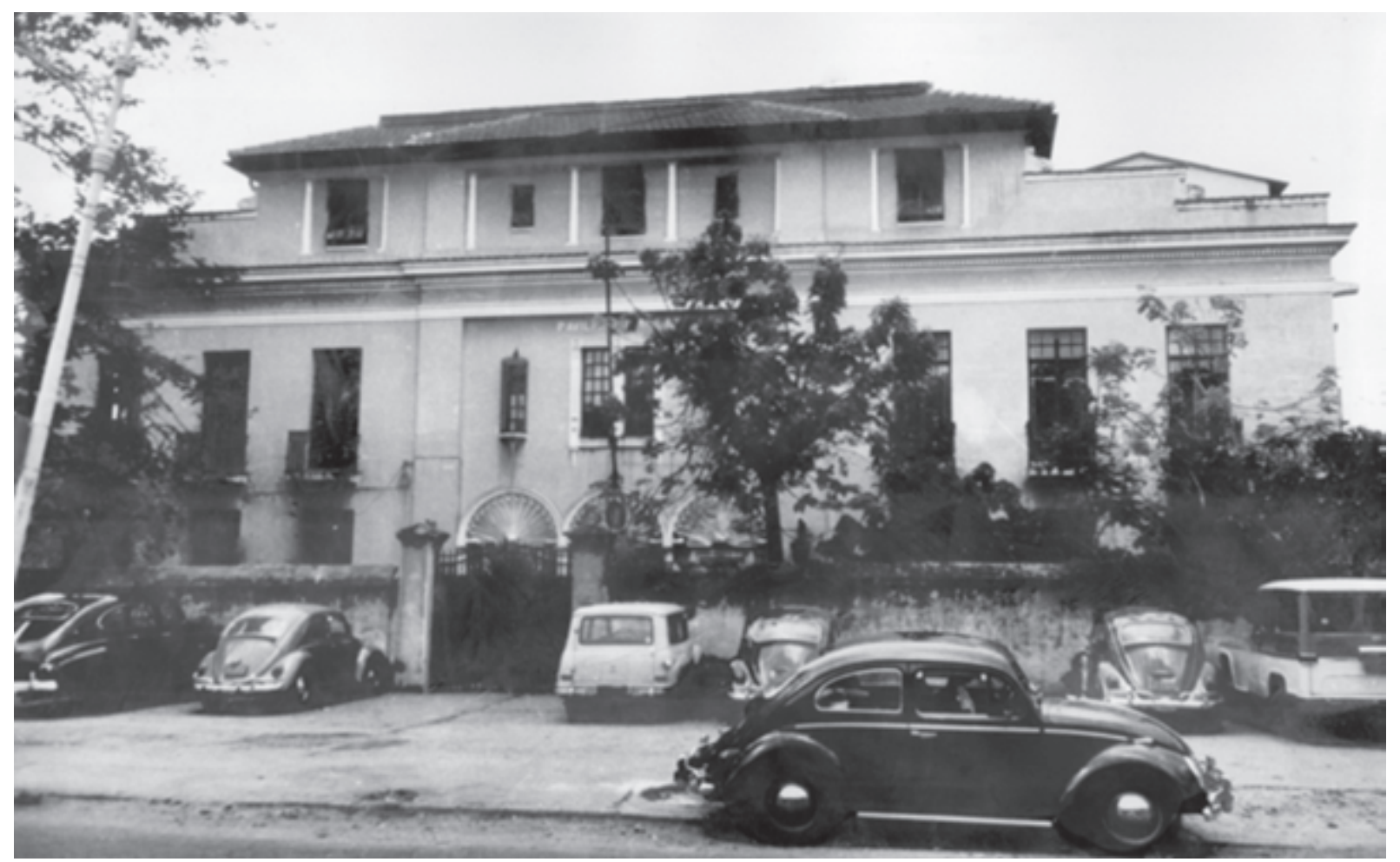

Escola de Enfermagem Anna Nery, [s.d.]. Acervo Universidade Federal do Rio de Janeiro

A Escola de Enfermagem Anna Nery foi criada em 1922 para formar um quadro de enfermeiras de saúde pública. Em 1926 iniciouse a construção de seu edifício-sede, em terreno pertencente ao Hospital São Francisco de Assis, onde eram realizadas as aulas práticas da escola. 


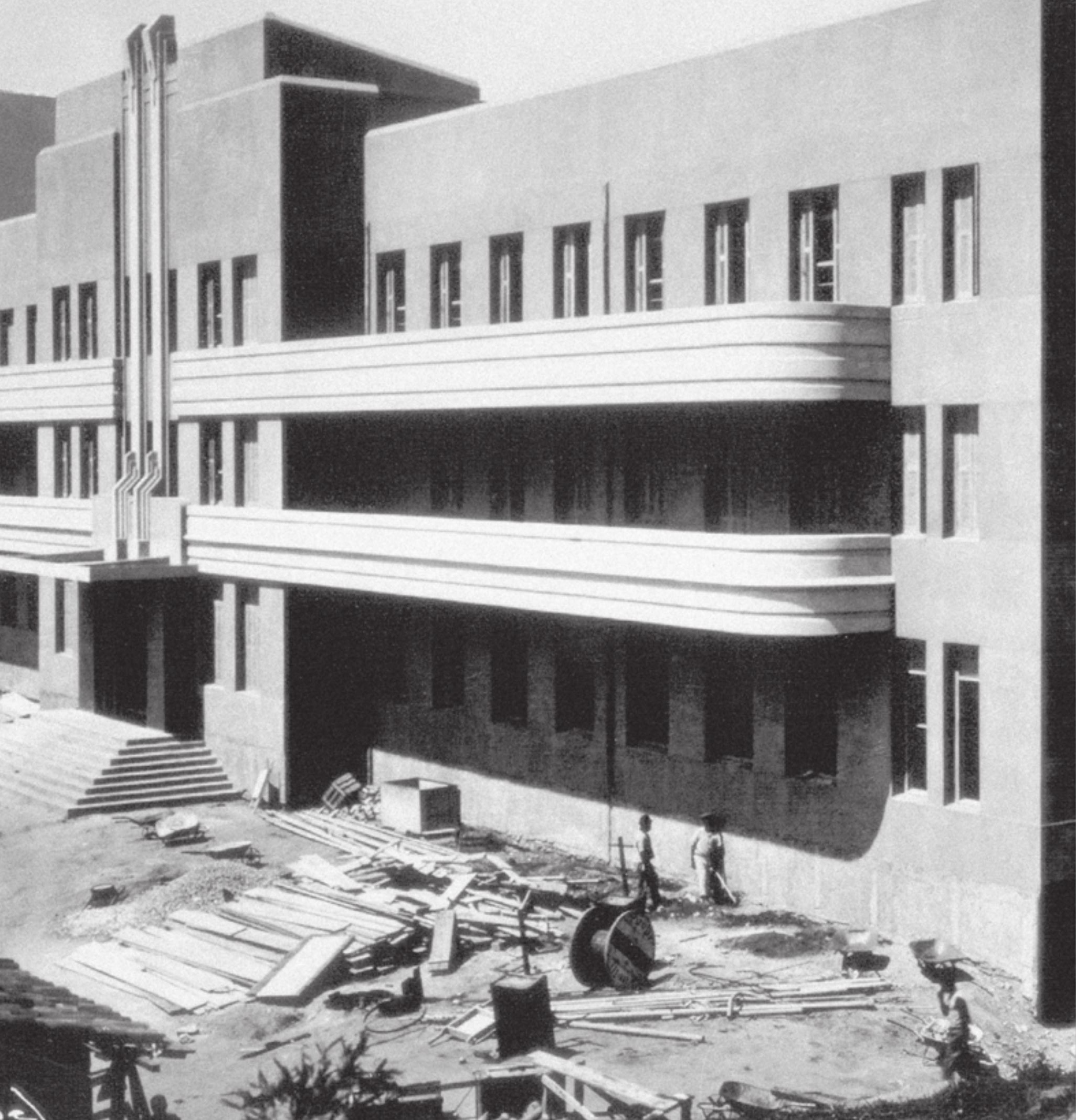

